\title{
Tulane
}

Tulane Economics Working Paper Series

\section{Revisiting the Income Tax Effects of Legalizing Same-sex Marriages}

\author{
James Alm \\ Department of Economics \\ Tulane University \\ jalm@tulane.edu
}

\author{
J. Sebastian Leguizamon \\ Department of Economics \\ Vanderbilt University \\ j.sebastian.leguizamon@ \\ vanderbilt.edu
}

Working Paper 1402
January 2014

\author{
Susane Leguizamon \\ Department of Economics \\ Western Kentucky University \\ susane.leguizamon@wku.edu
}

\begin{abstract}
In this paper, we estimate the impacts on income tax collections of legalizing same-sex marriage. We utilize new individual-level data sources to estimate the federal income tax consequences of legalizing same-sex marriages. These data sources also allow us to estimate the impact of legalization on state income tax collections. We find that 23 states would realize a net fiscal benefit from legalization, while 21 states $\mathrm{w}$ ould experience a decline in revenue. The potential (annual) changes in state tax revenue range from negative $\$ 29$ million in California to positive $\$ 16$ million in New York. At the federal level, our estimates suggest an overall reduction in revenues, ranging from a potential loss of $\$ 187$ million to $\$ 580$ million. Overall, we find that the federal and state impacts are quite modest. We also find that our estimates are only marginally affected by alternative assumptions about how many same-sex couples will choose to marry and which partner will claim any children for tax deduction purposes.
\end{abstract}

Keywords: marriage, individual income tax, marriage tax, taxable unit JEL codes: H24, J12, J16 


\title{
Revisiting the Income Tax Effects of Legalizing Same-sex Marriages
}

\author{
James Alm, J. Sebastian Leguizamon, and Susane Leguizamon
}

\begin{abstract}
In this paper, we estimate the impacts on income tax collections of legalizing same-sex marriage. We utilize new individual-level data sources to estimate the federal income tax consequences of legalizing same-sex marriages. These data sources also allow us to estimate the impact of legalization on state income tax collections. We find that 23 states would realize a net fiscal benefit from legalization, while 21 states would experience a decline in revenue. The potential (annual) changes in state tax revenue range from negative $\$ 29$ million in California to positive $\$ 16$ million in New York. At the federal level, our estimates suggest an overall reduction in revenues, ranging from a potential loss of $\$ 187$ million to $\$ 580$ million. Overall, we find that the federal and state impacts are quite modest. We also find that our estimates are only marginally affected by alternative assumptions about how many same-sex couples will choose to marry and which partner will claim any children for tax deduction purposes.
\end{abstract}

James Alm is professor and chair of the Department of Economics, Tulane University, 208 Tilton Hall, New Orleans, LA 70118 (phone +1 504862 8344; email jalm@ tulane.edu).

J. Sebastian Leguizamon is a professor in the Department of Economics, Vanderbilt University, VU Station B \#351819, 2301 Vanderbilt Place, Nashville, TN 37235-1819 (phone + 1615322 7353; email j.sebastian.leguizamon@vanderbilt.edu).

Susane Leguizamon is a professor in the Department of Economics, Western Kentucky University, 1906 College Heights Boulevard, Bowling Green, KY 42101 (phone: +1 270745 2635; email susane.leguizamon@wku.edu).

\section{ACKNOWLEDGEMENTS}

We are grateful to the Editor, Maureen Pirog, to the Co-Editor, Brad Heim, and to three anonymous referees for many helpful comments. We are also grateful to Wesley Howden, Rachel Donga, and Tamara Walker for the assistance in assembling and analyzing the data set, as part of the Tulane Research Experience for Undergraduates in Applied Microeconomics and Program Evaluation (Treu-Ampe), funded by the National Science Foundation and supervised by Professors Keith Finlay and Jonathan Pritchett. Daniel Feenberg provided invaluable help with the NBER TAXSIM calculations. 


\section{INTRODUCTION}

Gays and lesbians have made major efforts in recent years to be accepted into all aspects of mainstream American life. Many of these efforts have centered on winning the right to marry, and same-sex couples have gone to court in several states seeking this legal right. Indeed, public support for same-sex marriage has increased considerably in the last ten years, and most recent polls suggest that a slight majority of Americans now favor legal recognition, even though groups have also organized to vote down or preemptively to ban state recognition. With the repeal of Section 3 of the Defense of Marriage Act (DOMA) by the U.S. Supreme Court in June 2013 (United States v. Windsor), the federal government now defers to the states regarding the classification of "married" and "spouse". Consequently, the federal government now recognizes same-sex marriages for couples residing in states that have legalized same-sex marriage for federal tax and benefit purposes. By the same token, the federal government does not confer legal recognition of unions for couples in states that do not recognize same-sex marriage. Currently, thirteen states and the District of Columbia recognize same-sex marriages $;{ }^{1}$ many more states continue to explicitly define marriage as occurring between one man and one woman only, and most states do not recognize marriages of same-sex couples from other states. In this paper, we estimate the impacts on federal and state income tax collections of legalizing same-sex marriage.

There are many unresolved - and likely unresolvable - controversies surrounding samesex marriages, regarding such issues as the definition of marriage, the meaning of family, the notion of morality, the right of privacy, the influence of religion, and the scope of civil rights. There are also various economic issues related to marriage. One such economic consequence of

\footnotetext{
${ }^{1}$ These states include California, Connecticut, Delaware, Iowa, Maine, Maryland, Massachusetts, Minnesota, New Hampshire, New York, Rhode Island, Vermont, and Washington. Additionally, Colorado, Hawaii, Illinois, and New Jersey recognize same-sex civil unions.
} 
allowing same-sex couples to marry is the potential impact on federal and state tax revenue. ${ }^{2} \mathrm{~A}$ change in an individual's filing status from either single or head-of-household to married can sometimes trigger an increase in tax liability, referred to as a "marriage penalty" or a "marriage tax"; under other circumstances, it can lead to a decrease in tax liability (a "marriage bonus" or a "marriage subsidy"). There have been several attempts to estimate these income tax effects, notably by Alm, Badgett, and Whittington (2000) and the Congressional Budget Office (CBO) (2004), and more recently by Stevenson (2012). Alm, Badgett, and Whittington (2000) constructed a "representative household" to estimate the federal tax consequences in 1997, and concluded that legalization of same-sex marriage may generate additional revenues to the federal government of as much as $\$ 1$ billion annually. The CBO (2004) revised this estimate to $\$ 400$ million annually to account for the Economic Growth and Tax Relief Reconciliation Act of 2001, which reduced the marriage tax for many couples. More recently, Stevenson (2012) used individual-level data rather than a representative household to estimate the annual federal revenue impact of legalization before and after the Jobs and Growth Tax Relief Reconciliation Act (JGTRRA) of 2003. Pre-JGTRRA estimates showed a positive impact of legalization that ranged from $\$ 118$ million to $\$ 231$ million when labor responsive is considered; post-JGTRRA estimates were reduced to a range of $\$ 19$ million to $\$ 39$ million. $^{3}$

\footnotetext{
${ }^{2}$ Another economic issue is the potential impact on legalization on employer-provided benefits. For example, Buchmueller and Carpenter (2012) evaluated the effect of 2005 California legislation that required private employers to provide the same health benefits to employees in committed same-sex relationships as those provided to employees in different-sex marriages. They found that the reform had no effects on differences in insurance outcomes between gay and straight men, but that the reform may have reduced insurance disparities between lesbians and heterosexual women. There are of course many other issues.

${ }^{3}$ There are also several studies that focus on the state-level effects. For example, Badgett (2010) used American Community Survey individual-level data on same-sex couples in Massachusetts to estimate 2009 federal income tax liabilities for same-sex couples in Massachusetts if they filed jointly as a married couple and if they filed as two separate individuals; she found that 66 percent of the same-sex couples in Massachusetts would pay on average $\$ 2,325$ less in federal taxes if they could file as a married couple, 11 percent of same-sex couples in Massachusetts would see no change in their federal income taxes if filing as married, and the remaining 23 percent would see an average increase in taxes of $\$ 502$. Other studies examine the economic impact of legalization at the state level, including the impacts on state income tax collections and on the overall state budget. For example, see Badgett
} 
The differences between these various estimates are due to a number of features in the calculations: the differences in time period and the corresponding changes in incomes and tax features over these periods (e.g., 1997 versus 2001 versus 2003 versus 2009); the detail of income and other tax-related information (e.g., a representative household versus individuallevel data, standard deductions versus itemized deductions); and, especially, the assumptions about the numbers of same-sex couples and about their likely marriage behavior following legalization. Given the sensitivity of any calculations to income, to exemptions and other tax preferences, to the specific features of a tax code that has changed considerably over time, and to the size of the affected population, it is essential that estimates be based on current and accurate measures of these various factors.

Of some note, these previous studies have largely focused on the impact of legalization on changes in federal individual income tax revenues assuming same-sex marriage is legalized in all states. However, an individual state can choose independently to legalize same-sex marriage, changing the extent to which federal government tax revenues are influenced. Given the large differences in political support for legalization across states, it is likely that state legalization, if it does occur, will be done on a case-by-case basis. Given also that state income tax codes vary significantly, coupled with regional variation of same-sex couple characteristics that also varies significantly, the fiscal impact of same-sex marriage on state budgets seems likely to vary dramatically across states. Also, studies that have examined the overall economic impact within a state have typically found a net benefit to the state. ${ }^{4}$

(1998), Badgett, Sears, and Kukura (2005a, 2005b), Badgett et al. (2007), Badgett et al. (2008), Sears and Badgett (2008), Sears, Ramos, and Badgett (2009), Herman, Konnoth, and Badgett (2011), among others. Many of these studies have been done by researchers at the Williams Institute of the UCLA School of Law (http://williamsinstitute.law.ucla.edu/).

${ }^{4}$ For example, see Kastanis, Badgett, and Herman (2012) for analysis of legalization in the State of Washington. These calculations include wedding and tourism expenditures generated by legalization. Again, see the many studies done by researchers at the Williams Institute of the UCLA School of Law. 
Calculating the marriage tax/subsidy for heterosexual couples is a surprisingly difficult exercise (Alm \& Whttington, 1996). Calculating the income tax consequences for same-sex couples is even more difficult. The calculation requires information on such variables as the number of gay and lesbian individuals, the number in same-sex relationships, the number in relationships who would marry, and, especially, their income and other tax-related characteristics (e.g., deductions, exclusions, and exemptions). Perhaps because of these difficulties, many previous estimates have tended to rely upon average tendencies generated from various surveys, as captured in a "representative household". Such estimates are useful and make the calculations straightforward. Even so, this approach makes it difficult to generalize beyond these stylized taxpayers.

However, much has changed in the tax landscape and beyond since many of these estimates were first made, and there are now more reliable and more recent data sources that make calculation of the tax/subsidy at the household level possible. We utilize these new data sources to estimate the federal income tax consequences of legalizing same-sex marriages. These data sources also allow us to estimate the impact of legalization on state income tax collections. Our estimates therefore provide, for the first time, a comprehensive and current look at the federal and state income tax consequences of legalizing same-sex marriage.

We find that 23 states would realize a net fiscal benefit from legalization, while 21 states would experience a decline in revenue; the remaining seven states do not levy income taxes and consequently would not be affected. Of the 13 states that currently recognize same-sex marriage, four are estimated to experience a tax revenue decline, seven are estimated to experience an increase, and the remaining two states do not collect state income taxes. The potential (annual) changes in state tax revenue for all states range from negative \$29 million in California to 
positive $\$ 16$ million in New York. At the federal level, our estimates suggest a reduction in federal revenue of $\$ 187$ million to $\$ 580$ million. Overall, we find that the federal and state income tax effects are very small. We also find that our estimates are only marginally affected by alternative assumptions about how many same-sex couples will choose to marry and which partner will claim any children for tax deduction purposes.

\section{A BRIEF HISTORY OF MARRIAGE TAXES AND SUBSIDIES IN THE}

\section{UNITED STATES}

The individual income tax in the United States was established in 1913, and its treatment of the family has varied over time. In its early years, the basic unit of taxation was the individual, in which each individual was taxed on the basis of his or her income independently of marital status. Because the tax liability did not change much with marriage, the income tax was largely marriage neutral. However, the Revenue Act of 1948 changed the unit of taxation from the individual to the family. With the adoption of income splitting for married couples, couples were now allowed to aggregate and to divide in half their income for federal tax purposes. This change meant that families with equal incomes paid equal taxes. However, because of the progressive tax rates in the income tax, it also meant that a couple's joint tax liability could fall when they married. The Revenue Act of 1948 therefore created the potential for a couple to receive a marriage subsidy.

It was not until the Tax Reform Act of 1969 that a widespread and significant marriage penalty was created for many married couples. The 1969 act established (effective in 1971) a separate tax schedule for single persons that insured that a single person would incur a maximum tax liability of 120 percent of a married couple with equal income. Although the tax schedule for 
married persons was not changed, the act effectively increased the tax liability of some married tax filers relative to single filers, especially for couples whose partners had similar earnings. Marriage now could lead to a substantial increase in income tax liabilities for many couples. The 1969 act therefore generated the potential for a significant marriage tax, even though a potential marriage subsidy still existed for some couples.

Over the last 40 years or so, various tax changes have markedly affected the potential for a marriage tax or subsidy. In particular, the Economic Growth and Tax Relief Reconciliation Act of 2001 (EGTRRA) and the Jobs and Growth Tax Relief Reconciliation Act of 2003 (JGTRRA) both cut taxes in such a way as to effectively eliminate the marriage penalty for low-income households (Gale \& Potter, 2002). ${ }^{5}$ These measures, combined with the remaining potential marriage subsidies/penalties resulting from the tax system, imply that tax liability changes as a result of marriage are extremely sensitive to assumptions about individual earnings and taxable income. If, for example, same-sex couples are comprised of one earner or two earners with very unequal incomes, it is likely that they will gain from being able to file as married, resulting in a decrease in government revenues. If instead same-sex couples are instead comprised largely of equal-earning couples, it is likely that they will pay more when married, resulting in an increase in government revenues. ${ }^{6}$ However, recent research has found that many same-sex couples do specialize similarly to hetero-sexual couples, at least when children are present (Black, Sanders, \& Taylor, 2007).

\footnotetext{
${ }^{5}$ These tax cuts did not eliminate the entire marriage penalty once one includes the effect of an increase in family income resulting from marriage on qualification for government transfers.

${ }^{6}$ Historically same-sex couples have been assumed to be less likely to have children and, together with the implications resulting from gender-based discrimination, same-sex couples have been assumed to be part of a twoearner couple (Becker, 1991; Alm, Badgett, \& Whittington, 2000). In contrast, Becker (1991) predicted that heterosexual couples would choose to specialize in either home production or labor market production, implying more single-earner hetero-sexual couples.
} 


\section{DATA AND METHODOLOGY}

We use data from the 2010 American Community Survey (ACS) to estimate the tax consequences of legalization. ${ }^{7}$ The ACS is an annual survey conducted by the Census Bureau that is a 1-in-100 random representative sample of households of the overall population in the United States. The Census interviews all members of the household, obtaining information on each individual's annual income from work, social security, public welfare, investments, and other income sources. The ACS also provides information on the age, race, marital status, gender, and number of dependents for each of the persons living under the same household.

Individuals identify themselves by providing their relationship to the head of household. The ACS compiles information on 2 million individuals, single and married, coupled and living alone. Given that the sample provides a household identifier for each sampled individual, we can identify who in the household is a spouse, a child, a father-in-law, or an unmarried partner. Of special note, when a head of household and an unmarried partner in the same household are identified with the same gender, then the Census suggests that they are a same-sex couple living in cohabitation, so same-sex couples can be identified from head of households who claim an unmarried same-sex partner living with them (Black et al., 2000). Note that both the 1990 Census and the 2000 Census suffered from a biased estimate of the number of same sex cohabiting couples, resulting from the Census miscoding individuals who identified themselves as married to a same-sex individual. This miscoding was corrected in the 2010 Census following a procedure suggested by Gates and Steinberger (2010); see also Gates (2010). Note also that we are able to identify who in the ACS has an opposite sex unmarried partner, which means they are heterosexual couples living in cohabitation.

\footnotetext{
${ }^{7}$ The ACS data used to determine family characteristics, income, and potential tax deductions were obtained from the Minnesota Population Center (Ruggles et al., 2010).
} 
Once these same-sex cohabitating couples are identified, we can use the household weights provided by the ACS to calculate the approximate number of cohabitating same-sex couples in the United States. Similar to the uncorrected Census estimates, there is the possibility of measurement error. If couples who appear to be same-sex couples are actually heterosexual couples who have marked the wrong gender when answering the questionnaire, our estimates will be biased. However, the corrected estimation of number of same-sex couples by the Census is larger than the raw estimation obtained from the ACS data. If all couples whose marital status has been allocated by the Census are dropped from the ACS estimates, the estimations are roughly halved relative to the original estimates and more than halved relative to the Census corrected summary estimates. Given this, it is likely that the estimates obtained without dropping these observations are more appropriate, although we do provide these alternative estimates in our Sensitivity Analysis, as discussed later. ${ }^{8}$

Using the household weights provided by the Census, we estimate that there are approximately 526,452 same-sex couples living together in the United States, an estimate that is in line with previous estimates (Graham \& Barr, 2008). Table 1 describes the estimated (weighted) number of same-sex couples in each state, as well as the percentage of couples in one-earner versus two-earner households. An average of 24 percent of all same-sex couples are single-earner couples, ranging from 5 percent in North Dakota to 41 percent in Arkansas.

Estimating the number of same-sex couples who would marry if same-sex marriage is legalized by the states is not a straight-forward procedure. The assumed marriage rate will affect our projected tax revenue/loss. Our initial estimation assumes that the number of same-sex couples who would marry if legally allowed to do so is based simply on the total estimated

\footnotetext{
${ }^{8}$ We provide a comparison of the estimated number of same-sex couples and the corresponding effects on the estimated income tax revenue changes for each specification (e.g., the original ACS numbers, the ACS numbers with re-allocated observations dropped, and the Census estimated numbers) in Tables 12 and 13.
} 
number of same-sex couples currently living together (or 526,452 couples in our household sample), without considering those who are cohabiting but who choose not to marry; this initial estimation also does not consider those who are not cohabitating and thus not captured by our household sample.

Of course, the number of same-sex couples who would marry following legalization cannot be known. Some recent studies for individual states (Badgett, Sears, \& Kukura, 2005a, 2005b; Badgett, 2010) assume a more modest 50 percent marriage rate, based upon observed marriage rates in states following legalization in these states. Accordingly, we test the sensitivity of our initial results by using this alternative assumption of a 50 percent marriage rate.

However, it seems plausible that the federal recognition of same-sex marriages will result in higher marriage rates than when only states recognize same-sex marriage. Federal benefits are more comprehensive, and in some cases result in significantly higher tax and legal benefits. Additionally, the 50 percent estimates are based on the number of couples who marry immediately following legalization or soon after. Given the current uncertainty of state recognition, it is likely that a higher percent of same-sex couples will marry over time as more states legalize same-sex marriages. Furthermore, the overall marriage rate of heterosexuals in the United States is estimated to be between 51 percent (currently married) and 72 percent (ever married) (Cohn et al., 2011). If we make similar assumptions with respect to the homosexual population, this suggests that over 1 million same-sex couples will marry, far higher than our assumption that 526,452 couples will marry.

Regardless of these considerations, we include estimates that assume a more conservative 50 percent marriage rate, as noted. We also include estimates that assume that even more couples than those living together choose to marry and estimates that assume that same-sex couples 
marry at the same rate as heterosexual couples. These alternative scenarios are discussed in our sensitivity analysis.

In order to obtain the most accurate estimate of each person's income tax liability, we gather individual-level information on wage income, business and farm income, social security income, dividends, number of children, property taxes, and mortgage payments. ${ }^{9}$ Information on annual mean and median earned income by state is in Table 2 . The mean and median wages are separated by the higher earner and lower earner in the case of the two-earner households with unequal incomes. Note that the mean earned incomes are considerably higher than the median, suggesting influential outliers and also suggesting that researchers must be wary of estimates based on a single representative agent obtained from national or state averages. ${ }^{10}$

Each person's tax liability in the sample is calculated using the NBER's TAXSIM simulation tool. ${ }^{11}$ TAXSIM allows us to input data on individuals' income and other assets, number of dependents, assumed filing status (i.e. single, married, or head of household), whether a filer is 65 years of age or older, state of residence, and the desired tax year. In return, TAXSIM provides the estimated federal and state tax liabilities and their corresponding marginal tax rates for each person for the year specified. When the filing status is set to married, the simulator also includes the spouse's earned income as part of the couple's tax liability estimation.

We calculate each couple's potential marriage tax/subsidy in three steps. First, we use each individual's information to calculate the individual liability before. In cases where the

\footnotetext{
${ }^{9}$ Interest paid on mortgage was calculated by assuming that home-owning households are 15 years into a 30 -year mortgage with a fixed interest rate of 6.5 percent. This interest rate represents a 15 -year average mortgage interest rate obtained from Freddie Mac. This includes home equity loans or second mortgages and takes the mean and median interest paid for each state representative household.

${ }^{10}$ The presence and magnitude of the marriage tax/subsidy depends heavily on the relative wages of the coupled individuals. To that end, couples are classified as a "one-earner household" if only one partner works for wages and as a "two-earner household" if both partners earn wages; two-earner households are further classified as "equal earner" if each partner earns the same gross wage and as "unequal earner" if the gross wages differ.

${ }^{11}$ We are grateful to Daniel Feenberg for his help with the NBER TAXSIM calculations.
} 
couple reported having children, we allocated those to the person who claimed the child on the Census (we also estimate the tax revenue changes assuming the higher earner and, separately, the lower earner claims any children in our Sensitivity Analysis section). ${ }^{12}$ We then estimate each couple's total liability by adding the liabilities of the two individual filers. Note that we also assume a "head of household" filing status when possible (e.g. single individuals with dependents), allowing some individuals to lower their potential tax liability even further.

Second, we estimate the each couple's tax liability assuming they were allowed to file as a married couple. Instead of leaving the spouse's income and wages TAXIM field empty, we add it to the calculation and change the filing status to "married".

Third, each couple's marriage tax/subsidy is then calculated as the difference between the tax liability as a married couple and the aggregated tax liability found when adding the liabilities as separate filers; a positive number indicates an increase in tax liabilities (e.g., a marriage penalty/tax), and a negative number indicates a marriage bonus/subsidy. The tax revenue consequences at the federal and state levels are obtained by using the corresponding household weights.

As with our sensitivity analysis that examines the impact of different assumptions about the marriage rate of same-sex couples, we also conduct sensitivity analysis on the impact of alternative assumptions about which partner claims any children for tax deduction purposes (e.g., the higher earning partner versus the lower earning partner). All results are discussed in the next section.

\footnotetext{
${ }^{12}$ We suspect that a non-trivial portion of these children are the product of previous relationships rather than jointly adopted, and so they cannot legally be claimed by the same-sex partner even if it would lower their joint tax liability. Adopted children make up a very small portion of the overall sample, and it is not possible to tell from our data if any adopted children have been adopted by both partners.
} 


\section{ESTIMATIONS}

\section{Main Results}

We first consider the estimates obtained when we assume that all states legalize same-sex marriage and, separately, the estimated tax revenue implications of the states that have already legalized same-sex marriage. We present estimates at the state level and at the federal level; we also present estimates for one-earner couples separately from two-earner couples. Later we examine several alternative scenarios regarding the sensitivity of child allocation for tax deduction purposes and several in which we make different assumptions about marriage patterns of same-sex couples.

Our state-level estimates using individual level data when all states legalize same-sex marriage are provided in Table 3 (aggregate estimates) and Table 4 (weighted average across households); we also present estimates when individuals are assumed to take the standard deduction, even when this increases their tax liability. ${ }^{13}$ New York is estimated to gain the most revenue from legalization, ranging from an increase in tax revenue of $\$ 10.8$ to $\$ 15.8$ million; in contrast, California is estimated to lose $\$ 28.8$ million. In total, state governments experience a decrease in income tax collections, but the aggregate impact is small and negative ( $-\$ 2.6$ million to $-\$ 18$ million). See also Figure 1 for the state patterns.

At the per household level (Table 4), one-earner couples in California on average see the largest decrease in their per household state tax liability upon marriage (or about \$950), while those in West Virginia and Utah see the largest increase in tax liability (roughly \$200). Two-

\footnotetext{
${ }^{13}$ Note that the tax-minimizing estimation does not imply that we assume that all couples itemize; rather, we assume that couples will choose to itemize if it reduces their overall tax liability. In some cases, individuals in a household may itemize when unmarried, but may then take the standard deduction when married (or vice-versa), if this minimizes their overall liabilities. For 22 of the states that have income taxes, the standard deduction estimation is identical to the tax-minimizing estimation because the couples in the sample do not have sufficiently high qualifying deductions to warrant itemizing.
} 
earner couples fare the best in Hawaii with a reduction in estimated liability of $\$ 380$, while those in New York would see the largest increase (\$630).

The federal impact of legalization is significantly larger (Tables 5 and 6 and Figure 2). These federal tax revenue consequences are broken down by state, but remember that these estimates represent only the federal income tax liabilities, not the state tax liabilities. Our estimates indicate a reduction in federal tax revenue that ranges from $-\$ 187$ million to $-\$ 475$ million (Table 5). ${ }^{14}$ At the household level (Table 6), we estimate an average decrease for samesex couples to be $-\$ 316$ when individuals are assumed to minimize their tax liabilities; when individuals are assumed to take the standard deduction, the average change in tax liability becomes $-\$ 718 .^{15}$

There is considerable variation across states in the federal income tax consequences. On average, same-sex couples in Connecticut will pay slightly over $\$ 1,000$ more in federal taxes if they choose to wed, while couples in Pennsylvania will pay about $\$ 800$ less. If we consider oneearner and two-earner couples separately, one-earner couples will pay as much as $\$ 9,100$ less in Alaska, but they will pay roughly the same amount in Nebraska before and after marriage. ${ }^{16}$ Similarly, two-earner couples will see the largest drop in federal tax liability in South Carolina ($\$ 570)$ and the largest increase in the District of Columbia $(\$ 1,400)$

Unlike differences in state-imposed state income taxes, federal taxes must treat all individuals the same, so that differences in the per household estimates are a result of differences in family structure, income, and deductions. For same-sex couples in particular, the differential

\footnotetext{
${ }^{14}$ Our negative result is comparable to the results obtained by Stevenson (2012) when he assumes an instantaneous penalty; his estimation based on the assumption of an endogenous penalty is larger, but still modest.

${ }^{15}$ Although it may seem counterintuitive that the marriage subsidy decreases when we minimize taxes, it occurs because individuals stand to gain a larger amount from itemizing as a single filer relative to filing as married. Remember that we are measuring the difference in tax liabilities rather than the overall level of tax liability. ${ }^{16}$ Our estimates suggest larger effects in Wyoming, North Dakota, and Montana, but these states do not seem to present an appropriate comparison given their relatively small sample sizes. See our later discussion in Sensitivity Analysis.
} 
appears to be largely driven by differences in income. In Alaska the average one-earner household earns an average of $\$ 100,000$ while the average one-earner household in Nebraska earns only $\$ 7,500$. Consequently, we estimate that one-earner couples in Nebraska will not experience the large reduction in tax liability upon marriage that one-earner same-sex couples in Alaska will experience. Similarly, in South Carolina, the higher earner of a two-earner household earns $\$ 56,000$ on average while the lower earner earns an average of $\$ 21,000$. In the District of Columbia, on the other hand, the higher earner earns $\$ 113,000$ on average while the lower earner earns an average of $\$ 62,000$. Averaged across same-sex households, those in South Carolina will face a lower tax burden upon marriage due to the low wages of the lower earning spouse.

Note that some care must be taken when we interpret tax revenue changes in states with few (unweighted) observations. For example, in Wyoming there are only three same-sex couples that are used to estimate the general population of same-sex couples. States with low numbers of same-sex couple samples include Alaska, North and South Dakota, Montana, and Wyoming. Eliminating the influence of these states does not change our general findings. However, in most states the number of unweighted observations is quite large. For example, in California there are 2176 observations, in Texas there are 1002 observations, and in Florida there are 1104 observations; the average number of observations (other than in the outlier states) is $276 .{ }^{17}$

The estimated spatial distribution of the marriage tax for same-sex couples in the contiguous 48 states is given in Figures 3 and 4, which depict the weighted average change in households' state income tax liability and federal income tax liability, respectively (averaged across households in each state).

Given the recent Supreme Court ruling that grants same-sex couples who are in marriages recognized by their state to have their marriage recognized by the federal government, we also

\footnotetext{
${ }^{17}$ Unweighted sample sizes for all states are reported in Table 1.
} 
estimate the tax liability changes for states that currently recognize same-sex marriage or civil unions. These are a subset of our previous estimations, and are found in Table 7. Our estimations suggest that the federal income tax revenues will decline by approximately $\$ 74.2$ million as a result of the recent ruling.

\section{Sensitivity Analysis}

We consider several potential scenarios that may alter our aggregate estimates. It is possible that a couples' tax liability may be lowered if someone other than the person who claimed a child on the Census claims the child for tax deduction purposes. ${ }^{18}$ We re-estimate the tax consequences assuming that the higher earning partner and, separately, the lower earning partner claims any present children as dependents. The changes in aggregate state and federal tax liabilities are quite modest and can be found in Tables 8 and 9. The estimated state income tax change increases a bit when the higher earner claims any children (ranging from positive \$2.7 million to negative $\$ 11.7$ million), and decreases when the lower earner claims any children ($\$ 10.3$ million to $-\$ 26.3$ million).

As previously noted, the assumed marriage rate following legalization is unknown. Similar to Badgett, Sears, and Kukura (2005a, 2005b) and Badgett (2010), we have also estimated the revenue impacts when we assume that only 50 percent of co-habiting same-sex couples marry if allowed (rather than assuming that all co-habiting couples marry if allowed). This alternative assumption halves our estimates to an even more modest reduction of $\$ 1.3$ million to $\$ 9$ million for states and $-\$ 95$ million to $-\$ 237$ million for the federal government. Similarly, we have estimated the revenue impacts if even more couples than those living together

\footnotetext{
${ }^{18}$ As previously mentioned, there are likely legal deterrents that prohibit unmarried same-sex couples from choosing which partner will claim any children present as dependents.
} 
choose to marry, say, 75 percent of couples choose to marry, again with minor impacts on our estimates. Other scenarios are of course possible. It is estimated that there are 4 million gays and lesbians in the United States (Gates \& Steinberger, 2010). If same-sex couples marry at the same rate as heterosexuals, or 51 percent, according to the Census Bureau (2011), then there would be 960,000 same-sex married couples. This is almost double our current estimates, suggesting that state revenues may decrease by as much as $\$ 36$ million and that federal revenues would have a potential annual loss of almost $\$ 1$ billion $^{19}$

It is also plausible that couples who face large penalties may choose to marry at a relatively lower rate than couples who do not face large penalties. The range of subsidies/penalties faced by households at the state level and federal level are provided in Table 10. At the high end, some couples face a federal tax liability increase of over $\$ 15,000$ in Massachusetts while some couples in Delaware would face a federal tax liability reduction of almost $\$ 19,000$. At the state level, the largest reduction in state tax liability is almost $\$ 6,000$ for some couples in Hawaii and the largest increase in state tax liability is over $\$ 12,000$ for some couples in New York.

If we assume that couples who would face a federal tax liability increase of over $\$ 5,000$ would not marry if allowed, then both federal and state income tax revenues would experience an aggregated reduction. The reduction in federal income tax revenue would be approximately \$303.5 million (a drop of an additional \$116.4 million) while the reduction in aggregated state tax revenues would be around \$15.7 million (an additional \$5.4 million), summarized in Table 11, columns 2 and 3. Column 1 in Table 11 details the marriage tax of the $95^{\text {th }}$ percentile for couples in every state. For the majority of states this falls well below the $\$ 5,000$ mark,

\footnotetext{
${ }^{19}$ While the CBO (2004) assumed a 100 percent marriage rate of same-sex couples, Stevenson (2012) considered several potential marriage rates, including those suggested by Badgett (2010) and those that depend upon the demographics of the same-sex couples.
} 
suggesting that the majority of couples would still marry if indeed an increase of $\$ 5,000$ would entice these couples not to marry. If a change in tax liability less than $\$ 5,000$ would deter marriage, the net negative influence on federal income taxes would increase.

However, given the large size of the increased tax liability faces by these couples in particular, imposing this restriction does change the number of states that contribute a net positive change to the federal income tax. For the original estimates Arkansas, the District of Columbia, Delaware, Hawaii, Minnesota, New Jersey and Wisconsin were estimated to have couples paying a net positive average increase in federal income tax. Dropping couples whose federal income tax liability increased by more than $\$ 5,000$ eliminates Arkansas, the District of Columbia, Hawaii and Minnesota from this statistic.

The estimated change in state income tax revenue if these couples are assumed to not marry is detailed in column 3 in Table 11. All 23 states that were previously estimated to experience a net increase in revenues are still estimated to experience an increase ${ }^{20}$ New York is still the state with the largest estimated increase (\$5.3 million), but this is roughly one-third of the original estimated increase ( $\$ 15.8$ million). California, the state that is estimated to lose the most state income tax revenue, would experience an additional drop of approximately $\$ 2$ million, adjusting the aggregated net decline in state income tax revenues to approximately $\$ 30.8$ million.

\section{CONCLUSIONS}

The income taxes paid by same-sex couples are one of many potential effects of legalizing same-sex marriage. We provide updated estimates of potential federal government revenue changes using current and individual-level data. We also consider the potential impacts

\footnotetext{
${ }^{20}$ Additionally, Connecticut, which was not previously estimated to experience an increase, now is estimated to experience an increase. This is because the restriction of eliminating couples whose federal tax liability increased by more than \$5,000 also eliminated some couples who were experiencing an estimated reduction in state tax liability.
} 
on state government income tax collections of legalization.

Overall, we find quite modest impacts on state budgets, on federal collections, and on per household liabilities. In total, states are estimated to gain on an annual basis between $\$ 6.7$ million and \$23.7 million in additional state income tax under the most plausible set of assumptions, but may generate as much as $\$ 48$ million or as little as $\$ 3$ million. New York is projected to experience the largest increase in additional tax revenues ( $\$ 12$ million), while California will experience the least (-\$21 million). Same-sex couples in Ohio will pay the largest state per household marriage penalty $(\$ 380)$, while couples in California will receive the largest subsidy (-\$272). In all, we estimate that 31 states will gain additional income tax revenues, 12 will lose, and seven will experience no change. At the federal level, our estimates range from an annual gain of $\$ 5.7$ million to an annual loss of $-\$ 315.8$ million. For both the state and federal tax liability changes, the distribution of the effects varies significantly across the states. Again, however, the effects are small.

Our estimates are of course dependent upon the many assumptions that we necessarily made: on the number of gay and lesbian individuals, the number in relationships, the number in relationships who would marry, their labor supply responses, and their income and use of tax preferences. We have considered several alternative scenarios, and generally found our base estimates to be only marginally affected. Behavioral changes, if any, will also influence our estimations. For example, if as a result of marriage same-sex couples have more children, then this will increase the available deductions, decrease federal income tax revenue, and also reduce any projected gain to many states. Similarly, an increased probability of homeownership by married same-sex households will increase deductions and reduce taxable income further. Although marriage taxes/subsidies have been shown to have a small impact on the probability of 
marriage (Alm \& Whittington, 1997), it is possible that those couples who would see an increase in their tax liability will choose to remain unmarried.

Even though these revenue effects in the aggregate are typically modest, individual couples may still experience large changes in their income tax liabilities simply from a change in legal marital status. Any such changes in taxes do not need to occur, and are entirely dependent on how the tax law defines the unit of taxation (Alm, Dickert-Conlin, \& Whittington, 1999). An income tax system that defines the unit as the family will exhibit the types of changes in tax liabilities that we have calculated here. In contrast, in a tax system that makes the individual the unit of taxation, a couple's tax liability will not change simply because of a change in legal marital status. Indeed, the dominant current practice in income tax systems around the world is to designate the individual rather than the family as the unit of taxation (Alm \& Melnik, 2005). Given the enormous, and increasing, range of "family" types in the United States - traditional singleearner households with a stay-at-home spouse, two-earner families, non-marital cohabitation among opposite and same-sex couples, extended families, unrelated individuals living together it may well be time to recognize that the tax laws of such a diverse society should treat all families the same. The choice to make the individual the unit of taxation would ensure that tax liabilities are independent of legal marital status. The recent legal cases regarding same-sex marriages make it even more pressing that this choice be addressed.

\section{REFERENCES}

Alm, J., \& Melnik, M. I. (2005). Taxing the "family" in the individual income tax. Public Finance and Management, 5, 67-109.

Alm, J., \& Whittington, L. A. (1997). Income taxes and the timing of marital decisions. Journal of Public Economics, 64, 219-240.

Alm, J., Badgett, M. V. L., \& Whittington, L. A. (2000). Wedding bell blues: The income tax consequences of legalizing same-sex marriage. National Tax Journal, 66, 297-316. 
Alm, J., Dickert-Conlin, S., \& Whittington, L. A. (1999). The marriage tax. The Journal of Economic Perspectives, 13, 193-204.

Amato, P. R. (2007). Strengthening marriage is an appropriate social policy goal. Journal of Policy Analysis and Management, 26, 952-955.

Badgett, M. V. L. (1998). The fiscal i mpact on the state of Vermont of allowing same-sex couples to marry. Technical Report, Amherst, MA: Institute for Gay and Lesbian Strategic Studies.

Badgett, M. V. L. (2010). The economic value of marriage for same-sex couples. Drake Law Review, 58, 1081-1116.

Badgett, M. V. L., Baumle, A., Dravich, S., Romero, A., \& Sears, B. (2007). The impact on Maryland's budget of allowing same-sex couples to marry. The Williams Institute, Research Report. Los Angeles, CA: UCLA School of Law.

Badgett, M. V. L., Baumle, A., Romero, A., \& Sears, B. (2008). The impact on Iowa's budget of allowing same-sex couples to marry. The Williams Institute, Research Report. Los Angeles, CA: UCLA School of Law.

Badgett, M. V. L., Sears, B., \& Kukura, E. (2005a). Counting on couples: Fiscal savings from allowing same-sex couples to marry in Connecticut. The Williams Institute, Research Report. Los Angeles, CA: UCLA School of Law.

Badgett, M. V. L., Sears, B., \& Kukura, E. (2005b). The impact on New Hampshire's budget of allowing same-sex couples to marry. The Williams Institute, Research Report. Los Angeles, CA: UCLA School of Law.

Becker, G. S. (1991). Treatise on the Family. Cambridge, MA: Harvard University Press.

Black, D., Sanders, S., \&Taylor, L. (2000). Demographics of the gay and lesbian population in the United States: Evidence from available data sources. Demography, 37, 139-154.

Black, D., Sanders, S., \& Taylor, L. (2007). The economics of gay and lesbian families. The Journal of Economic Perspectives, 21, 53-70.

Buchmueller, T. C., \& Carpenter, C. S. (2012). The effect of requiring private employers to extend health benefit eligibility to same-sex partners of employees: Evidence from California. Journal of Policy Analysis and Management, 31, 388-403.

Cohn, D’V., Passel, J. S., Wang, W., \& Livingston, G. (2011). Barely half of U.S. adults are married - A record low. Pew Research, Social and Demographic Trends, available online at http://www.pewsocialtrends.org/2011/12/14/barely-half-of-u-s-adults-aremarried-a-record-low/.

Feenberg, D., \& Coutts, E. (1993). An introduction to the TAXSIM Model. Journal of Policy Analysis and Management, 12, 189-194.

Furstenberg, F. F. (2007). Should government promote marriage? Journal of Policy Analysis and Management, 26, 956-960.

Gates, G. J. (2010). Same-sex couples in U.S. Census Bureau data: Who gets counted and why. The Williams Institute, Research Report. Los Angeles, CA: UCLA School of Law.

Gale, W. G. \& Potter, S. R. (2002). An economic evaluation of the Economic Growth and Tax Reconciliation Act of 2001. National Tax Journal, 55, 133-186.

Gates, G. J. (2010). Same-sex couples in U.S. Census Bureau data: Who gets counted and why. The Williams Institute, Research Report. Los Angeles, CA: UCLA School of Law.

Gates, G. J., \& Steinberger, M. (2010). Same-sex unmarried couples in the American Community Survey: The role of misreporting, miscoding, and misallocation. The Williams Institute, Research Report. Los Angeles, CA: UCLA School of Law. 
Glaeser, E. (2002). The benefits of the home mortgage interest deduction. NBER Working Paper 9284. Cambridge, MA: National Bureau of Economic Research.

Graham, J., \& Barr, J. (2008). Assessing the geographic distribution of same-sex and opposite-sex couples across the United States: Implications for claims of causality between traditional marriage and same-sex unions. Review of Economics of the Household, 6, 347-367.

Herman, J., Konnoth, C., \& Badgett, M. V. L. (2011). The impact on Rhode Island's budget of allowing same-sex couples to marry. The Williams Institute, Research Report. Los Angeles, CA: UCLA School of Law.

Holtz-Eakin, D. (2004). The potential budgetary impact of recognizing same-sex marriages. Report for Subcommittee on the Constitution, Congressional Budget Office. Washington, D.C.

Kastanis, A., Badgett, M. V. L., \& Herman, J. (2012). The economic impact of extending marriage to same-sex couples in Washington State. The Williams Institute, Research Report. Los Angeles, CA: UCLA School of Law.

Ramos, C. \& Badgett, M. V. L. (2009). The impact on Maine's budget of allowing same-sex couples to marry. The Williams Institute, Research Report. Los Angeles, CA: UCLA School of Law.

Ruggles, S., Alexander, J. T., Genadek, K., Goeken, R., Schroder, M., \& Sobek, M. (2010). Integrated public use microdata series: Version 5.0 [Machine-readable database]. Minneapolis, MN: University of Minnesota.

Sears, B., \& Badgett, M. V. L. (2008). The impact of extending marriage to same-sex couples on the California budget. The Williams Institute, Research Report. Los Angeles, CA: UCLA School of Law.

Sears, B., Ramos, C., \& Badgett, M. V. L. (2009). The impact of extending marriage to samesex couples on the New Jersey budget. The Williams Institute, Research Report. Los Angeles, CA: UCLA School of Law.

Stevenson, A. (2012). The labor supply and tax revenue consequences of federal same-sex marriage legalization. National Tax Journal, 65, 783-806.

United States Bureau of the Census (2011). America's Families and Living Arrangements: 2011. Washington, D.C.: Bureau of the Census. 
Table 1. Number and Percent of One- and Two-earner Same-sex Households

\begin{tabular}{|c|c|c|c|c|c|c|}
\hline \multirow[b]{2}{*}{ State } & \multicolumn{2}{|c|}{$\begin{array}{c}\text { One-Earner Hous ehold } \\
\text { Couples }\end{array}$} & \multicolumn{2}{|c|}{$\begin{array}{c}\text { Two-Earner Hous ehold } \\
\text { Couples } \\
\end{array}$} & \multicolumn{2}{|c|}{$\begin{array}{c}\text { Total Hous e hold } \\
\text { Couples } \\
\end{array}$} \\
\hline & $\begin{array}{l}\text { Weighted } \\
\text { Number }\end{array}$ & Percent & $\begin{array}{l}\text { Weighted } \\
\text { Number }\end{array}$ & Percent & $\begin{array}{l}\text { Weighted } \\
\text { Number }\end{array}$ & $\begin{array}{c}\text { Sample } \\
\text { Size }\end{array}$ \\
\hline Alabama & 876 & $19 \%$ & 3,847 & $81 \%$ & 4,723 & 60 \\
\hline Alaska & 74 & $7 \%$ & 955 & $93 \%$ & 1,029 & 11 \\
\hline Arizona & 3,803 & $29 \%$ & 9,334 & $71 \%$ & 13,137 & 174 \\
\hline Arkansas & 1,491 & $41 \%$ & 2,112 & $59 \%$ & 3,603 & 37 \\
\hline California & 22,242 & $28 \%$ & 57,793 & $72 \%$ & 80,035 & 1,088 \\
\hline Colorado & 1,719 & $15 \%$ & 9,815 & $85 \%$ & 11,534 & 123 \\
\hline Connecticut & 2,127 & $29 \%$ & 5,315 & $71 \%$ & 7,442 & 91 \\
\hline Delaware & 147 & $10 \%$ & 1,277 & $90 \%$ & 1,424 & 31 \\
\hline District of Columbia & 243 & $8 \%$ & 2,679 & $92 \%$ & 2,922 & 40 \\
\hline Florida & 10,931 & $32 \%$ & 22,829 & $68 \%$ & 33,760 & 507 \\
\hline Georgia & 4,015 & $27 \%$ & 10,845 & $73 \%$ & 14,860 & 190 \\
\hline Hawaï & 702 & $29 \%$ & 1,723 & $71 \%$ & 2,425 & 26 \\
\hline Idaho & 349 & $29 \%$ & 872 & $71 \%$ & 1,221 & 20 \\
\hline Illinois & 4,284 & $23 \%$ & 14,206 & $77 \%$ & 18,490 & 229 \\
\hline Indiana & 1,674 & $18 \%$ & 7,720 & $82 \%$ & 9,394 & 120 \\
\hline Iowa & 724 & $16 \%$ & 3,727 & $84 \%$ & 4,451 & 42 \\
\hline Kansas & 890 & $24 \%$ & 2,771 & $76 \%$ & 3,661 & 44 \\
\hline Kentucky & 1,125 & $19 \%$ & 4,744 & $81 \%$ & 5,869 & 79 \\
\hline Louisiana & 1,676 & $30 \%$ & 3,922 & $70 \%$ & 5,598 & 75 \\
\hline Maine & 659 & $18 \%$ & 2,919 & $82 \%$ & 3,578 & 44 \\
\hline Maryland & 2,013 & $21 \%$ & 7,766 & $79 \%$ & 9,779 & 124 \\
\hline Massachusetts & 3,789 & $19 \%$ & 15,946 & $81 \%$ & 19,735 & 246 \\
\hline Michigan & 3,183 & $26 \%$ & 9,199 & $74 \%$ & 12,382 & 145 \\
\hline Minnesota & 2,229 & $20 \%$ & 9,088 & $80 \%$ & 11,317 & 110 \\
\hline Mississippi & 702 & $32 \%$ & 1,471 & $68 \%$ & 2,173 & 31 \\
\hline Missouri & 1,463 & $15 \%$ & 8,613 & $85 \%$ & 10,076 & 98 \\
\hline Montana & 186 & $15 \%$ & 1,076 & $85 \%$ & 1,262 & 12 \\
\hline Nebraska & 582 & $26 \%$ & 1,634 & $74 \%$ & 2,216 & 27 \\
\hline Nevada & 1,304 & $23 \%$ & 4,350 & $77 \%$ & 5,654 & 73 \\
\hline New Hampshire & 345 & $12 \%$ & 2,563 & $88 \%$ & 2,908 & 32 \\
\hline New Jersey & 3,649 & $26 \%$ & 10,466 & $74 \%$ & 14,115 & 179 \\
\hline New Mexico & 1,192 & $26 \%$ & 3,441 & $74 \%$ & 4,633 & 62 \\
\hline New York & 9,819 & $25 \%$ & 29,214 & $75 \%$ & 39,033 & 476 \\
\hline North Carolina & 3,702 & $23 \%$ & 12,220 & $77 \%$ & 15,922 & 188 \\
\hline North Dakota & 34 & $5 \%$ & 717 & $95 \%$ & 751 & 9 \\
\hline Ohio & 3,795 & $24 \%$ & 12,346 & $76 \%$ & 16,141 & 208 \\
\hline Oklahoma & 738 & $16 \%$ & 3,929 & $84 \%$ & 4,667 & 50 \\
\hline Oregon & 1,712 & $21 \%$ & 6,534 & $79 \%$ & 8,246 & 101 \\
\hline Pennsylvania & 4,515 & $23 \%$ & 15,269 & $77 \%$ & 19,784 & 220 \\
\hline Rhode Island & 699 & $25 \%$ & 2,058 & $75 \%$ & 2,757 & 40 \\
\hline South Carolina & 1,226 & $27 \%$ & 3,376 & $73 \%$ & 4,602 & 68 \\
\hline South Dakota & 105 & $20 \%$ & 414 & $80 \%$ & 519 & 5 \\
\hline Tennessee & 2,246 & $28 \%$ & 5,771 & $72 \%$ & 8,017 & 107 \\
\hline Texas & 7,881 & $20 \%$ & 31,351 & $80 \%$ & 39,232 & 501 \\
\hline Utah & 464 & $12 \%$ & 3,410 & $88 \%$ & 3,874 & 45 \\
\hline Vermont & 627 & $32 \%$ & 1,318 & $68 \%$ & 1,945 & 24 \\
\hline Virginia & 2,183 & $20 \%$ & 8,842 & $80 \%$ & 11,025 & 137 \\
\hline Washington & 2,708 & $18 \%$ & 12,363 & $82 \%$ & 15,071 & 171 \\
\hline West Virginia & 379 & $25 \%$ & 1,117 & $75 \%$ & 1,496 & 22 \\
\hline Wisconsin & 1,154 & $15 \%$ & 6,683 & $85 \%$ & 7,837 & 85 \\
\hline Wyoming & 28 & $22 \%$ & 99 & $78 \%$ & 127 & 3 \\
\hline Nationally & 124,403 & $24 \%$ & 402,049 & $76 \%$ & 526,452 & 6,630 \\
\hline
\end{tabular}


Table 2. State Mean and Median Annual Personal Earned Income

\begin{tabular}{|c|c|c|c|c|c|c|c|c|}
\hline \multirow[b]{4}{*}{ State } & \multicolumn{4}{|c|}{ Mean Earned Income (\$) } & \multicolumn{4}{|c|}{ Median Earned Income (\$) } \\
\hline & \multirow[t]{3}{*}{$\begin{array}{c}\text { One-Earner } \\
\text { Couples }\end{array}$} & \multicolumn{3}{|c|}{ Two-Earner Couples } & \multirow[t]{3}{*}{$\begin{array}{c}\text { One-Earner } \\
\text { Couples }\end{array}$} & \multicolumn{3}{|c|}{ Two-Earner Couples } \\
\hline & & \multicolumn{2}{|c|}{ Unequal Earners } & \multirow[t]{2}{*}{$\begin{array}{c}\text { Equal } \\
\text { Earners } \\
\end{array}$} & & \multicolumn{2}{|c|}{ Unequal Earners } & \multirow[t]{2}{*}{$\begin{array}{r}\text { Equal } \\
\text { Earners } \\
\end{array}$} \\
\hline & & $\begin{array}{l}\text { High- } \\
\text { Earner }\end{array}$ & $\begin{array}{l}\text { Low- } \\
\text { Earner }\end{array}$ & & & $\begin{array}{l}\text { High- } \\
\text { Earner }\end{array}$ & $\begin{array}{l}\text { Low- } \\
\text { Earner }\end{array}$ & \\
\hline Alabama & 38,606 & 53,139 & 26,825 & 49,000 & 9,500 & 46,000 & 21,000 & 49,000 \\
\hline Alaska & 100,000 & 81,405 & 37,316 & 0 & 100,000 & 60,000 & 31,400 & 0 \\
\hline Arizona & 39,443 & 63,847 & 34,484 & 13,855 & 27,100 & 59,000 & 31,300 & 16,000 \\
\hline Arkansas & 18,963 & 50,976 & 18,357 & 123,000 & 19,000 & 26,200 & 18,000 & 123,000 \\
\hline California & 70,391 & 90,167 & 39,765 & 33,086 & 50,000 & 68,000 & 31,000 & 25,000 \\
\hline Colorado & 55,875 & 65,609 & 32,236 & 14,580 & 46,000 & 60,000 & 30,000 & 15,000 \\
\hline Connecticut & 65,525 & 93,419 & 43,884 & 0 & 80,000 & 75,000 & 33,700 & 0 \\
\hline District of Columbia & 199,749 & 113,293 & 62,523 & 16,500 & 100,000 & 100,000 & 48,500 & 16,500 \\
\hline Delaware & 6,305 & 84,565 & 32,741 & 31,000 & 860 & 68,000 & 32,000 & 31,000 \\
\hline Florida & 38,262 & 72,987 & 29,530 & 50,407 & 28,200 & 52,000 & 25,000 & 20,000 \\
\hline Georgia & 42,492 & 71,544 & 31,833 & 21,075 & 35,000 & 55,000 & 26,000 & 20,000 \\
\hline Hawaii & 40,321 & 114,873 & 77,420 & 25,000 & 52,000 & 70,000 & 38,900 & 25,000 \\
\hline Idaho & 21,481 & 36,336 & 18,370 & 0 & 12,100 & 31,300 & 17,000 & 0 \\
\hline Illinois & 56,070 & 91,714 & 38,846 & 30,066 & 40,000 & 68,000 & 33,000 & 20,000 \\
\hline Indiana & 49,827 & 54,211 & 24,577 & 19,000 & 38,900 & 49,000 & 23,800 & 20,000 \\
\hline Iowa & 34,569 & 45,988 & 29,376 & 18,000 & 40,000 & 42,000 & 30,000 & 18,000 \\
\hline Kansas & 26,463 & 51,438 & 23,019 & 18,500 & 23,500 & 42,000 & 19,000 & 18,500 \\
\hline Kentucky & 29,877 & 52,421 & 27,346 & 14,716 & 25,000 & 42,000 & 25,000 & 14,000 \\
\hline Louisiana & 43,415 & 74,279 & 27,101 & 15,375 & 36,900 & 55,000 & 21,000 & 20,000 \\
\hline Maine & 123,099 & 48,282 & 22,517 & 19,739 & 58,000 & 45,000 & 23,000 & 20,000 \\
\hline Maryland & 57,078 & 92,705 & 42,653 & 20,000 & 50,000 & 83,000 & 46,000 & 20,000 \\
\hline Massachusetts & 66,756 & 77,422 & 36,032 & 55,196 & 45,000 & 70,000 & 35,000 & 20,000 \\
\hline Michigan & 34,726 & 73,739 & 34,121 & 25,000 & 16,000 & 52,000 & 28,000 & 25,000 \\
\hline Minnesota & 55,574 & 72,918 & 37,037 & 17,321 & 24,000 & 60,000 & 34,000 & 19,500 \\
\hline Mississippi & 65,545 & 52,262 & 20,672 & 15,323 & 15,000 & 48,000 & 17,000 & 16,500 \\
\hline Missouri & 50,391 & 57,828 & 27,764 & 15,783 & 29,000 & 50,000 & 25,900 & 17,500 \\
\hline Montana & 2,932 & 32,212 & 19,158 & 0 & 900 & 21,600 & 3,500 & 0 \\
\hline Nebraska & 7,556 & 54,932 & 25,923 & 25,000 & 4,000 & 35,100 & 17,800 & 25,000 \\
\hline Nevada & 35,941 & 56,196 & 33,177 & 19,000 & 21,900 & 42,000 & 30,000 & 19,000 \\
\hline New Hampshire & 24,000 & 64,326 & 36,812 & 50,000 & 24,000 & 50,000 & 33,200 & 50,000 \\
\hline New Jersey & 106,548 & 86,006 & 35,638 & 23,552 & 49,000 & 69,000 & 35,000 & 28,500 \\
\hline New Mexico & 67,718 & 50,030 & 19,594 & 0 & 43,900 & 40,000 & 10,000 & 0 \\
\hline New York & 77,443 & 109,257 & 38,457 & 36,867 & 40,000 & 75,000 & 30,000 & 20,500 \\
\hline North Carolina & 34,507 & 59,819 & 25,492 & 17,542 & 30,000 & 49,000 & 25,000 & 23,000 \\
\hline North Dakota & 33,500 & 51,703 & 21,348 & 0 & 33,500 & 50,000 & 21,000 & 0 \\
\hline Ohio & 48,090 & 57,775 & 27,969 & 15,534 & 30,100 & 50,000 & 22,900 & 14,000 \\
\hline Oklahoma & 20,258 & 79,769 & 32,997 & 15,499 & 30,000 & 43,000 & 30,000 & 14,500 \\
\hline Oregon & 37,059 & 70,838 & 31,674 & 31,848 & 30,000 & 52,000 & 28,000 & 37,500 \\
\hline Pennsylvania & 52,318 & 76,615 & 33,956 & 15,360 & 35,000 & 60,000 & 30,000 & 14,500 \\
\hline Rhode Island & 66,496 & 85,140 & 30,198 & 33,500 & 50,000 & 64,000 & 22,000 & 33,500 \\
\hline South Carolina & 36,858 & 56,248 & 21,408 & 0 & 32,000 & 34,000 & 14,000 & 0 \\
\hline South Dakota & 9,000 & 30,181 & 27,281 & 0 & 9,000 & 25,000 & 24,000 & 0 \\
\hline Tennessee & 43,989 & 57,683 & 27,711 & 20,000 & 35,000 & 55,000 & 25,000 & 20,000 \\
\hline Texas & 50,692 & 73,143 & 34,151 & 21,269 & 36,000 & 59,200 & 30,000 & 22,500 \\
\hline Utah & 41,474 & 56,961 & 25,741 & 0 & 25,800 & 53,000 & 20,000 & 0 \\
\hline Vermont & 14,716 & 50,196 & 22,344 & 0 & 12,800 & 36,500 & 11,000 & 0 \\
\hline Virginia & 64,796 & 74,295 & 36,787 & 11,387 & 27,000 & 65,000 & 25,000 & 8,000 \\
\hline Washington & 46,048 & 74,996 & 33,051 & 25,093 & 30,000 & 58,000 & 30,000 & 18,000 \\
\hline West Virginia & 30,290 & 60,295 & 26,518 & 17,500 & 27,000 & 50,000 & 22,000 & 17,500 \\
\hline Wisconsin & 34,594 & 52,084 & 35,761 & 4,000 & 21,700 & 43,000 & 28,000 & 4,000 \\
\hline Wyoming & 25,000 & 24,000 & 3,278 & 0 & 25,000 & 24,000 & 3,500 & 0 \\
\hline National & 54,902 & 75,829 & 33,962 & 26,617 & 35,000 & 60,000 & 28,000 & 19,000 \\
\hline
\end{tabular}


Table 3. State Income Tax Revenue Effects of Same-Sex Marriage

\begin{tabular}{|c|c|c|c|c|c|c|}
\hline \multirow[b]{2}{*}{ State } & \multicolumn{2}{|c|}{ One-Earner Households (\$) } & \multicolumn{2}{|c|}{ Two-Earner House holds (\$) } & \multicolumn{2}{|c|}{ All Households (\$) } \\
\hline & Minimizing & Standard & Minimizing & Standard & Minimizing & Standard \\
\hline Alabama & 12,352 & 24,550 & 222,483 & 292,585 & 195,223 & 277,522 \\
\hline Alaska & 0 & 0 & 0 & 0 & 0 & 0 \\
\hline Arizona & $-525,967$ & $-525,967$ & 429,088 & 429,088 & $-486,346$ & $-486,346$ \\
\hline Arkansas & $-291,124$ & $-320,634$ & 77,572 & $-19,098$ & $-249,962$ & $-376,142$ \\
\hline California & $-21,100,000$ & $-21,100,000$ & $-3,643,648$ & $-3,643,648$ & $-28,800,000$ & $-28,800,000$ \\
\hline Colorado & $-225,012$ & $-421,662$ & 890,800 & $-206,320$ & 603,156 & $-690,616$ \\
\hline Connecticut & $-80,291$ & $-80,291$ & 232,736 & 232,736 & $-83,164$ & $-83,164$ \\
\hline Delaware & $-61,696$ & $-61,696$ & 71,501 & 71,501 & $-40,324$ & $-40,324$ \\
\hline District of Columbia & 3,445 & 5,370 & 957,816 & 950,046 & 961,260 & 955,416 \\
\hline Florida & 0 & 0 & 0 & 0 & 0 & 0 \\
\hline Georgia & $-609,512$ & $-759,747$ & $1,464,256$ & $1,898,476$ & 557,100 & 810,872 \\
\hline Hawaii & $-256,576$ & $-256,576$ & $-105,626$ & $-105,626$ & $-1,065,178$ & $-1,065,178$ \\
\hline Idaho & $-228,579$ & $-228,579$ & 88,509 & 88,509 & $-142,175$ & $-142,175$ \\
\hline Illinois & $-466,711$ & $-466,711$ & $-49,724$ & $-49,724$ & $-607,348$ & $-607,348$ \\
\hline Indiana & $-127,785$ & $-127,785$ & 197,698 & 197,698 & 65,948 & 65,948 \\
\hline Iowa & $-4,186$ & $-43,328$ & 359,605 & 150,546 & 309,728 & 62,986 \\
\hline Kansas & $-117,207$ & $-165,189$ & 166,963 & $-68,275$ & 263,577 & $-19,643$ \\
\hline Kentucky & $-182,330$ & $-182,330$ & 71,128 & 71,128 & $-200,854$ & $-200,854$ \\
\hline Louisiana & $-300,152$ & $-397,560$ & 48,247 & $-360,595$ & $-295,318$ & $-801,569$ \\
\hline Maine & $-405,758$ & $-459,947$ & 502,697 & 173,685 & $-74,390$ & $-455,932$ \\
\hline Maryland & $-322,100$ & $-398,928$ & 953,484 & 436,904 & 569,964 & $-23,440$ \\
\hline Massachusetts & $-558,583$ & $-558,583$ & 654,032 & 654,032 & $-238,464$ & $-238,464$ \\
\hline Michigan & $-480,258$ & $-480,258$ & $-277,388$ & $-277,388$ & $-481,736$ & $-481,736$ \\
\hline Minnesota & 395,067 & 171,225 & $3,512,664$ & $1,877,700$ & $3,898,380$ & $2,039,580$ \\
\hline Mississippi & $-118,521$ & $-126,686$ & 84,301 & 84,301 & $-77,298$ & $-85,463$ \\
\hline Missouri & $-393,825$ & $-466,230$ & 337,458 & $-366,976$ & 280,680 & $-496,160$ \\
\hline Montana & 3,660 & 3,660 & $-11,324$ & $-11,324$ & $-227,573$ & $-233,290$ \\
\hline Nebraska & -12424.86 & -12424.86 & 358,631 & 183,190 & 272,943 & 97,502 \\
\hline Nevada & 0 & 0 & 0 & 0 & 0 & 0 \\
\hline New Hampshire & 0 & 0 & $-3,120$ & $-3,120$ & $-3,120$ & $-3,120$ \\
\hline New Jersey & $-2,092,298$ & $-2,092,298$ & $1,363,532$ & $1,363,532$ & $-835,240$ & $-835,240$ \\
\hline New Mexico & 4,937 & $-92,425$ & 830,166 & 513,036 & 745,883 & 344,481 \\
\hline New York & $-4,694,600$ & $-5,538,096$ & $20,700,000$ & $16,600,000$ & $15,800,000$ & $10,800,000$ \\
\hline North Carolina & $-1,441,207$ & $-1,628,916$ & $1,240,176$ & $-288,264$ & $-513,688$ & $-2,270,992$ \\
\hline North Dakota & $-3,300$ & $-3,300$ & $-53,502$ & $-53,502$ & $-56,802$ & $-56,802$ \\
\hline Ohio & $-27,912$ & $-27,912$ & $4,984,254$ & $4,984,254$ & $4,933,772$ & $4,933,772$ \\
\hline Oklahoma & $-214,865$ & $-214,865$ & 688,340 & 282,836 & 509,476 & 103,972 \\
\hline Oregon & $-732,211$ & $-724,992$ & $1,551,124$ & $1,722,856$ & 726,684 & 905,640 \\
\hline Pennsylvania & $-744,449$ & $-744,449$ & $-266,884$ & $-266,884$ & $-1,109,220$ & $-1,109,220$ \\
\hline Rhode Island & $-133,053$ & $-133,053$ & 563,032 & 563,032 & 74,309 & 74,309 \\
\hline South Carolina & $-266,798$ & $-310,093$ & 700,781 & 337,807 & 328,461 & $-77,808$ \\
\hline South Dakota & 0 & 0 & 0 & 0 & 0 & 0 \\
\hline Tennessee & $-19,077$ & $-19,077$ & $-25,194$ & $-25,194$ & $-63,738$ & $-63,738$ \\
\hline Texas & 0 & 0 & 0 & 0 & 0 & 0 \\
\hline Utah & 84,049 & 39,204 & 503,114 & 113,872 & 595,347 & 161,259 \\
\hline Vermont & $-115,988$ & $-155,989$ & 385,896 & 205,969 & 237,939 & 36,033 \\
\hline Virginia & $-252,261$ & $-478,846$ & 543,440 & $-397,420$ & 220,460 & $-946,988$ \\
\hline Washington & 0 & 0 & 0 & 0 & 0 & 0 \\
\hline West Virginia & 83,469 & 83,469 & 520,562 & 520,562 & 569,650 & 569,650 \\
\hline Wisconsin & $-351,396$ & $-303,885$ & 255,220 & 255,220 & 281,142 & 328,654 \\
\hline Wyoming & 0 & 0 & 0 & 0 & 0 & 0 \\
\hline Total & $-37,371,034$ & $-39,781,830$ & $42,074,895$ & $29,111,741$ & $-2,641,152$ & $-18,124,157$ \\
\hline
\end{tabular}

Note: State numbers over $\$ 10$ million have been rounded to the nearest $\$ 100,000$ 
Table 4. State Income Tax Revenue Effects of Same-sex Marriage Averaged Across SameSex Couples

\begin{tabular}{|c|c|c|c|c|c|c|}
\hline \multirow[b]{2}{*}{ State } & \multicolumn{2}{|c|}{ One-Earner Hous eholds (\$) } & \multicolumn{2}{|c|}{ Two-Earner Households (\$) } & \multicolumn{2}{|c|}{ All House holds (\$) } \\
\hline & Minimizing & Standard & Minimizing & Standard & Minimizing & Standard \\
\hline Alabama & 14.1 & 28.0 & 40.0 & 55.3 & 35.8 & 50.9 \\
\hline Alaska & 0.0 & 0.0 & 0.0 & 0.0 & 0.0 & 0.0 \\
\hline Arizona & -138.3 & -138.3 & 3.5 & 3.5 & -32.0 & -32.0 \\
\hline Arkansas & -195.3 & -215.0 & 16.6 & -22.3 & -62.9 & -94.6 \\
\hline California & -950.2 & -950.2 & -114.2 & -114.2 & -322.9 & -322.9 \\
\hline Colorado & -130.9 & -245.3 & 77.5 & -25.2 & 48.6 & -55.7 \\
\hline Connecticut & -37.7 & -37.7 & -0.4 & -0.4 & -9.4 & -9.4 \\
\hline Delaware & -419.7 & -419.7 & 13.0 & 13.0 & -22.5 & -22.5 \\
\hline District of Columbia & 14.2 & 22.1 & 357.5 & 354.6 & 329.0 & 327.0 \\
\hline Florida & 0.0 & 0.0 & 0.0 & 0.0 & 0.0 & 0.0 \\
\hline Georgia & -151.8 & -189.2 & 95.7 & 128.9 & 34.4 & 50.0 \\
\hline Hawaii & -365.5 & -365.5 & -386.5 & -386.5 & -381.2 & -381.2 \\
\hline Idaho & -655.0 & -655.0 & 58.6 & 58.6 & -78.0 & -78.0 \\
\hline Illinois & -108.9 & -108.9 & -8.8 & -8.8 & -30.0 & -30.0 \\
\hline Indiana & -76.3 & -76.3 & 21.7 & 21.7 & 6.2 & 6.2 \\
\hline Iowa & -5.8 & -59.8 & 77.7 & 26.3 & 65.0 & 13.2 \\
\hline Kansas & -131.7 & -185.6 & 120.0 & 45.9 & 64.9 & -4.8 \\
\hline Kentucky & -162.1 & -162.1 & -2.8 & -2.8 & -26.2 & -26.2 \\
\hline Louisiana & -179.1 & -237.2 & 1.1 & -90.3 & -48.0 & -130.4 \\
\hline Maine & -615.7 & -697.9 & 87.3 & 1.1 & -16.7 & -102.4 \\
\hline Maryland & -160.0 & -198.2 & 104.3 & 43.9 & 53.9 & -2.2 \\
\hline Massachusetts & -147.4 & -147.4 & 18.5 & 18.5 & -11.3 & -11.3 \\
\hline Michigan & -150.9 & -150.9 & -0.1 & -0.1 & -33.5 & -33.5 \\
\hline Minnesota & 177.2 & 76.8 & 357.6 & 190.7 & 324.2 & 169.6 \\
\hline Mississippi & -168.8 & -180.5 & 23.7 & 23.7 & -31.7 & -35.0 \\
\hline Missouri & -269.2 & -318.7 & 73.9 & -3.3 & 26.5 & -46.8 \\
\hline Montana & 19.7 & 19.7 & -182.4 & -186.9 & -156.5 & -160.4 \\
\hline Nebraska & -21.3 & -21.3 & 132.2 & 50.9 & 99.6 & 35.6 \\
\hline Nevada & 0.0 & 0.0 & 0.0 & 0.0 & 0.0 & 0.0 \\
\hline New Hampshire & 0.0 & 0.0 & -1.1 & -1.1 & -1.0 & -1.0 \\
\hline New Jersey & -573.4 & -573.4 & 104.7 & 104.7 & -53.4 & -53.4 \\
\hline New Mexico & 4.1 & -77.5 & 168.4 & 99.3 & 133.4 & 61.6 \\
\hline New York & -478.1 & -564.0 & 629.9 & 503.1 & 372.8 & 255.6 \\
\hline North Carolina & -389.3 & -440.0 & 69.3 & -48.0 & -30.1 & -132.9 \\
\hline North Dakota & -97.1 & -97.1 & -52.9 & -52.9 & -54.4 & -54.4 \\
\hline Ohio & -7.4 & -7.4 & 361.8 & 361.8 & 281.8 & 281.8 \\
\hline Oklahoma & -291.1 & -291.1 & 162.6 & 71.6 & 98.1 & 20.0 \\
\hline Oregon & -427.7 & -423.5 & 201.0 & 224.7 & 81.0 & 101.0 \\
\hline Pennsylvania & -164.9 & -164.9 & -20.3 & -20.3 & -49.4 & -49.4 \\
\hline Rhode Island & -190.3 & -190.3 & 72.8 & 72.8 & 20.9 & 20.9 \\
\hline South Carolina & -217.6 & -252.9 & 142.7 & 55.7 & 60.9 & -14.4 \\
\hline South Dakota & 0.0 & 0.0 & 0.0 & 0.0 & 0.0 & 0.0 \\
\hline Tennessee & -8.5 & -8.5 & -6.7 & -6.7 & -7.1 & -7.1 \\
\hline Texas & 0.0 & 0.0 & 0.0 & 0.0 & 0.0 & 0.0 \\
\hline Utah & 181.1 & 84.5 & 139.4 & 33.3 & 144.1 & 39.0 \\
\hline Vermont & -185.0 & -248.8 & 232.2 & 126.0 & 110.6 & 16.8 \\
\hline Virginia & -115.6 & -219.4 & 48.7 & -48.2 & 18.5 & -79.6 \\
\hline Washington & 0.0 & 0.0 & 0.0 & 0.0 & 0.0 & 0.0 \\
\hline West Virginia & 220.2 & 220.2 & 351.0 & 351.0 & 322.9 & 322.9 \\
\hline Wisconsin & -304.5 & -263.3 & 86.0 & 86.0 & 33.1 & 38.6 \\
\hline Wyoming & 0.0 & 0.0 & 0.0 & 0.0 & 0.0 & 0.0 \\
\hline Average & -158 & -179 & 72 & 41 & 26 & -3 \\
\hline
\end{tabular}


Table 5. Federal Income Tax Revenue Effects of Same-sex Marriage

\begin{tabular}{|c|c|c|c|c|c|c|}
\hline \multirow[b]{2}{*}{ State } & \multicolumn{2}{|c|}{ One-Earner Hous eholds (\$) } & \multicolumn{2}{|c|}{ Two-Earner Households (\$) } & \multicolumn{2}{|c|}{ All Households (\$) } \\
\hline & Minimizing & Standard & Minimizing & Standard & Minimizing & Standard \\
\hline Alabama & $-1,013,807$ & $-1,257,773$ & $-912,636$ & $-2,314,604$ & $-1,925,428$ & $-3,542,764$ \\
\hline Alaska & $-674,603$ & $-674,603$ & 556,394 & $-48,260$ & $-118,206$ & $-722,862$ \\
\hline Arizona & $-4,340,127$ & $-5,992,932$ & $4,431,928$ & $-1,103,896$ & $-2,427,408$ & $-9,595,008$ \\
\hline Arkansas & $-251,293$ & $-251,293$ & 547,264 & $-444,896$ & 164,774 & $-827,388$ \\
\hline California & $-47,300,000$ & $-63,000,000$ & $23,700,000$ & $-11,500,000$ & $-32,000,000$ & $-83,000,000$ \\
\hline Colorado & $-3,605,823$ & $-4,357,294$ & $-168,144$ & $-4,538,648$ & $-4,129,296$ & $-9,251,248$ \\
\hline Connecticut & $-5,488,960$ & $-6,758,584$ & $3,074,872$ & 768,384 & $-4,305,520$ & $-7,930,496$ \\
\hline Delaware & $-72,893$ & $-72,893$ & 787,634 & 162,998 & 963,750 & 324,838 \\
\hline District of Columbia & $-737,232$ & $-959,868$ & $3,801,752$ & $1,905,112$ & $3,064,528$ & 945,248 \\
\hline Florida & $-16,400,000$ & $-19,600,000$ & $2,480,000$ & $-11,900,000$ & $-17,500,000$ & $-35,500,000$ \\
\hline Georgia & $-5,646,754$ & $-7,539,712$ & $-852,832$ & $-5,467,952$ & $-8,767,408$ & $-15,200,000$ \\
\hline Hawaii & $-1,271,141$ & $-1,350,631$ & $3,937,224$ & $3,179,208$ & 173,680 & $-906,632$ \\
\hline Idaho & $-505,961$ & $-660,684$ & $-588,048$ & $-824,427$ & $-1,098,504$ & $-1,489,606$ \\
\hline Illinois & $-8,657,170$ & $-10,900,000$ & $2,863,328$ & $-6,564,192$ & $-6,414,144$ & $-18,100,000$ \\
\hline Indiana & $-1,910,435$ & $-2,483,473$ & $-536,616$ & $-3,381,624$ & $-2,524,944$ & $-5,942,984$ \\
\hline Iowa & $-2,262,163$ & $-2,609,551$ & $1,246,942$ & $-143,084$ & $-1,225,226$ & $-2,978,886$ \\
\hline Kansas & $-770,053$ & $-1,101,616$ & $-441,122$ & $-1,333,598$ & $-1,180,680$ & $-2,404,718$ \\
\hline Kentucky & $-1,745,991$ & $-1,868,892$ & 396,500 & $-1,247,704$ & $-2,412,296$ & $-4,179,404$ \\
\hline Louisiana & $-2,851,427$ & $-3,458,070$ & $-1,018,976$ & $-3,216,152$ & $-4,116,500$ & $-6,920,320$ \\
\hline Maine & $-1,216,686$ & $-1,800,496$ & $-432,732$ & $-1,769,548$ & $-2,072,496$ & $-3,997,256$ \\
\hline Maryland & $-3,511,675$ & $-4,702,206$ & $3,522,736$ & $-1,326,848$ & $-205,600$ & $-6,252,256$ \\
\hline Massachusetts & $-3,108,872$ & $-5,547,940$ & $2,191,648$ & $-8,186,208$ & $-2,928,768$ & $-15,800,000$ \\
\hline Michigan & $-4,337,233$ & $-4,993,351$ & $3,117,488$ & $-2,234,592$ & $-2,343,104$ & $-8,312,496$ \\
\hline Minnesota & $-2,080,880$ & $-3,056,864$ & $2,943,552$ & $-1,334,064$ & 658,224 & $-4,595,376$ \\
\hline Mississippi & $-1,403,765$ & $-1,561,470$ & $-179,769$ & $-562,715$ & $-1,793,834$ & $-2,334,486$ \\
\hline Missouri & $-2,289,694$ & $-2,594,563$ & $-773,296$ & $-4,995,488$ & $-3,985,984$ & $-8,513,048$ \\
\hline Montana & $-12,469$ & $-12,469$ & $-379,333$ & $-474,775$ & $-904,150$ & $-1,089,525$ \\
\hline Nebraska & $-10,441$ & $-10,441$ & 234,682 & 25,556 & $-32,888$ & $-243,682$ \\
\hline Nevada & $-1,614,054$ & $-2,103,770$ & 811,440 & $-1,698,792$ & $-1,113,416$ & $-4,115,948$ \\
\hline New Hampshire & $-475,669$ & $-475,669$ & $1,551,656$ & 99,608 & $1,022,880$ & $-429,168$ \\
\hline New Jersey & $-6,474,320$ & $-13,100,000$ & $4,348,768$ & $-3,780,496$ & $-3,582,240$ & $-18,300,000$ \\
\hline New Mexico & $-2,194,540$ & $-2,743,318$ & $-355,204$ & $-1,666,386$ & $-3,315,892$ & $-5,207,072$ \\
\hline New York & $-20,600,000$ & $-28,900,000$ & $11,300,000$ & $-8,173,376$ & $-11,400,000$ & $-39,300,000$ \\
\hline North Carolina & $-4,642,740$ & $-5,477,600$ & $-4,315,144$ & $-10,600,000$ & $-9,638,480$ & $-16,900,000$ \\
\hline North Dakota & $-37,740$ & $-37,740$ & $-622,702$ & $-622,702$ & $-660,441$ & $-660,441$ \\
\hline Ohio & $-9,294,116$ & $-10,100,000$ & 27,032 & $-5,829,360$ & $-10,800,000$ & $-17,700,000$ \\
\hline Oklahoma & $-455,418$ & $-455,418$ & 103,072 & $-1,531,364$ & $-359,624$ & $-1,994,060$ \\
\hline Oregon & $-3,696,378$ & $-4,374,708$ & $-2,129,904$ & $-4,125,488$ & $-6,168,344$ & $-8,806,512$ \\
\hline Pennsylvania & $-7,473,128$ & $-9,874,642$ & $3,394,368$ & $-7,129,968$ & $-5,311,520$ & $-18,200,000$ \\
\hline Rhode Island & $-1,319,872$ & $-1,637,549$ & $-236,996$ & $-1,816,104$ & $-2,912,992$ & $-4,796,740$ \\
\hline South Carolina & $-839,057$ & $-1,175,631$ & $-1,199,896$ & $-2,326,496$ & $-3,211,672$ & $-4,674,848$ \\
\hline South Dakota & 0 & 0 & $-301,292$ & $-415,290$ & $-301,292$ & $-415,290$ \\
\hline Tennessee & $-3,599,748$ & $-4,182,304$ & $-1,745,600$ & $-4,103,204$ & $-6,858,224$ & $-9,798,384$ \\
\hline Texas & $-14,800,000$ & $-18,100,000$ & $4,694,944$ & $-13,800,000$ & $-9,945,216$ & $-31,800,000$ \\
\hline Utah & $-910,478$ & $-1,194,224$ & $-1,602,712$ & $-3,252,420$ & $-2,551,866$ & $-4,485,316$ \\
\hline Vermont & $-746,905$ & $-770,328$ & 61,708 & $-735,982$ & $-929,622$ & $-1,669,719$ \\
\hline Virginia & $-4,735,366$ & $-5,769,244$ & $-1,293,120$ & $-5,619,872$ & $-6,056,560$ & $-11,400,000$ \\
\hline Washington & $-3,672,090$ & $-4,615,600$ & 760,624 & $-7,519,248$ & $-4,971,712$ & $-13,900,000$ \\
\hline West Virginia & $-462,124$ & $-706,259$ & 173,377 & $-642,062$ & $-449,767$ & $-1,509,341$ \\
\hline Wisconsin & $-1,024,843$ & $-1,219,515$ & $2,814,864$ & $-11,360$ & $1,919,272$ & $-1,101,624$ \\
\hline Wyoming & $-42,805$ & $-42,805$ & $-126,341$ & $-130,176$ & $-169,146$ & $-172,981$ \\
\hline Total & $-212,588,938$ & $-276,233,992$ & $69,663,383$ & $-154,302,554$ & $-187,153,302$ & $-475,697,799$ \\
\hline
\end{tabular}

Note: State numbers over $\$ 10$ million have been rounded to the nearest $\$ 100,000$ 
Table 6. Federal Income Tax Revenue Effects of Same-sex Marriage Averaged Across SameSex Couples

\begin{tabular}{|c|c|c|c|c|c|c|}
\hline \multirow[b]{2}{*}{ State } & \multicolumn{2}{|c|}{ One-Earner House holds (\$) } & \multicolumn{2}{|c|}{ Two-Earner Hous eholds (\$) } & \multicolumn{2}{|c|}{ All Hous e holds (\$) } \\
\hline & Minimizing & Standard & Minimizing & Standard & Minimizing & Standard \\
\hline Alabama & $-1,157.3$ & $-1,435.8$ & -199.2 & -499.2 & -353.1 & -649.7 \\
\hline Alaska & $-9,116.3$ & $-9,116.3$ & 500.8 & -43.4 & -99.8 & -610.0 \\
\hline Arizona & $-1,141.2$ & $-1,575.8$ & 167.7 & -315.8 & -159.6 & -630.8 \\
\hline Arkansas & -168.5 & -168.5 & 167.4 & -231.7 & 41.4 & -208.0 \\
\hline California & $-2,127.8$ & $-2,830.3$ & 228.6 & -300.1 & -359.5 & -931.6 \\
\hline Colorado & $-2,097.6$ & $-2,534.8$ & -49.0 & -458.1 & -333.0 & -746.0 \\
\hline Connecticut & $-2,580.6$ & $-3,177.5$ & 175.9 & -174.2 & $1,048.8$ & -895.8 \\
\hline Delaware & -495.9 & -495.9 & 631.3 & 242.2 & -486.3 & 181.6 \\
\hline District of Columbia & $-3,033.9$ & $-3,950.1$ & $1,419.1$ & 711.1 & 538.7 & 323.5 \\
\hline Florida & $-1,496.4$ & $-1,788.5$ & -40.0 & -543.5 & -435.2 & -881.4 \\
\hline Georgia & $-1,406.4$ & $-1,877.9$ & -256.1 & -630.4 & -541.1 & -939.5 \\
\hline Hawaii & $-1,810.7$ & $-1,924.0$ & 690.6 & 212.2 & 62.2 & -324.5 \\
\hline Idaho & $-1,449.7$ & $-1,893.1$ & -402.0 & -562.4 & -602.6 & -817.1 \\
\hline Illinois & $-2,020.8$ & $-2,551.6$ & 140.4 & -450.8 & -316.5 & -894.9 \\
\hline Indiana & $-1,141.2$ & $-1,483.6$ & -68.8 & -387.4 & -238.1 & -560.4 \\
\hline Iowa & $-3,124.5$ & $-3,604.4$ & 256.5 & -91.4 & -257.1 & -625.0 \\
\hline Kansas & -865.2 & $-1,237.8$ & -129.4 & -410.7 & -290.6 & -591.9 \\
\hline Kentucky & $-1,552.0$ & $-1,661.2$ & -102.0 & -353.7 & -315.0 & -545.8 \\
\hline Louisiana & $-1,701.3$ & $-2,063.3$ & -282.8 & -774.0 & -669.5 & $-1,125.4$ \\
\hline Maine & $-1,846.3$ & $-2,732.2$ & -225.5 & -578.9 & -465.3 & -897.5 \\
\hline Maryland & $-1,744.5$ & $-2,335.9$ & 386.6 & -181.2 & -19.5 & -591.8 \\
\hline Massachusetts & -820.5 & $-1,464.2$ & 10.4 & -590.1 & -138.7 & -746.9 \\
\hline Michigan & $-1,362.6$ & $-1,568.8$ & 178.3 & -296.8 & -163.1 & -578.6 \\
\hline Minnesota & -933.5 & $-1,371.4$ & 279.6 & -157.1 & 54.7 & -382.2 \\
\hline Mississippi & $-1,999.7$ & $-2,224.3$ & -224.3 & -444.5 & -734.9 & -956.4 \\
\hline Missouri & $-1,565.1$ & $-1,773.5$ & -185.7 & -648.0 & -376.2 & -803.4 \\
\hline Montana & -67.0 & -67.0 & -703.2 & -849.4 & -621.8 & -749.3 \\
\hline Nebraska & -17.9 & -17.9 & -10.4 & -108.1 & -12.0 & -88.9 \\
\hline Nevada & $-1,237.8$ & $-1,613.3$ & 103.5 & -416.1 & -181.3 & -670.3 \\
\hline New Hampshire & $-1,378.8$ & $-1,378.8$ & 525.8 & 16.3 & 320.1 & -134.3 \\
\hline New Jersey & $-1,774.3$ & $-3,600.3$ & 240.9 & -433.4 & -228.8 & $-1,171.5$ \\
\hline New Mexico & $-1,841.1$ & $-2,301.4$ & -254.8 & -559.8 & -592.9 & -931.0 \\
\hline New York & $-2,100.0$ & $-2,948.0$ & 284.8 & -317.7 & -268.5 & -927.9 \\
\hline North Carolina & $-1,254.1$ & $-1,479.6$ & -373.3 & -856.6 & -564.2 & -991.6 \\
\hline North Dakota & $-1,110.0$ & $-1,110.0$ & -615.9 & -615.9 & -632.0 & -632.0 \\
\hline Ohio & $-2,449.0$ & $-2,656.3$ & -111.4 & -556.1 & -618.1 & $-1,011.4$ \\
\hline Oklahoma & -617.1 & -617.1 & 21.5 & -345.3 & -69.2 & -383.9 \\
\hline Oregon & $-2,159.1$ & $-2,555.3$ & -340.6 & -610.6 & -687.7 & -981.8 \\
\hline Pennsylvania & $-1,655.2$ & $-2,187.1$ & 120.4 & -465.9 & -236.4 & -811.8 \\
\hline Rhode Island & $-1,888.2$ & $-2,342.7$ & -559.0 & $-1,108.5$ & -820.8 & $-1,351.6$ \\
\hline South Carolina & -684.4 & -958.9 & -569.0 & -839.1 & -595.2 & -866.4 \\
\hline South Dakota & 0.0 & 0.0 & -564.2 & -777.7 & -471.5 & -649.9 \\
\hline Tennessee & $-1,602.7$ & $-1,862.1$ & -486.0 & -837.7 & -766.3 & $-1,094.8$ \\
\hline Texas & $-1,883.0$ & $-2,299.8$ & 140.0 & -390.1 & -232.1 & -741.4 \\
\hline Utah & $-1,962.2$ & $-2,573.8$ & -447.6 & -897.5 & -617.7 & $-1,085.8$ \\
\hline Vermont & $-1,191.2$ & $-1,228.6$ & -119.9 & -590.2 & -432.2 & -776.3 \\
\hline Virginia & $-2,169.2$ & $-2,642.8$ & -136.0 & -581.4 & -509.1 & -959.7 \\
\hline Washington & $-1,356.0$ & $-1,704.4$ & -94.1 & -674.5 & -301.1 & -843.4 \\
\hline West Virginia & $-1,219.3$ & $-1,863.5$ & 8.9 & -579.8 & -255.0 & -855.6 \\
\hline Wisconsin & -888.1 & $-1,056.8$ & 400.5 & 16.0 & 225.7 & -129.5 \\
\hline Wyoming & $-1,528.8$ & $-1,528.8$ & $-1,276.2$ & $-1,314.9$ & $-1,331.9$ & $-1,362.1$ \\
\hline Average & $-1,623$ & $-1,989$ & -34 & -444 & -316 & -718 \\
\hline
\end{tabular}


Table 7. Federal and State Income Tax Revenue Effects of Same-sex Marriage for States that Currently Recognize Same-sex Unions

\begin{tabular}{lrrrr}
\hline & \multicolumn{2}{c}{ Fede ral Tax Reve vue } & \multicolumn{2}{c}{ State Tax Revenue } \\
\cline { 2 - 5 } State & \multicolumn{1}{c}{ Minimizing } & Standard & \multicolumn{1}{c}{ Minimizing } & \multicolumn{1}{c}{ Standard } \\
\hline California & $-32,000,000$ & $-83,000,000$ & $-28,800,000$ & $-28,800,000$ \\
Colorado & $-4,129,296$ & $-9,251,248$ & 603,156 & $-690,616$ \\
Connecticut & $-4,305,520$ & $-7,930,496$ & $-83,164$ & $-83,164$ \\
Delaware & 963,750 & 324,838 & $-40,324$ & $-40,324$ \\
Hawaii & 173,680 & $-906,632$ & $-1,065,178$ & $-1,065,178$ \\
Illinois & $-6,414,144$ & $-18,100,000$ & $-607,348$ & $-607,348$ \\
Iowa & $-1,225,226$ & $-2,978,886$ & 309,728 & 62,986 \\
Maine & $-2,072,496$ & $-3,997,256$ & $-74,390$ & $-455,932$ \\
Maryland & $-205,600$ & $-6,252,256$ & 569,964 & $-23,440$ \\
Massachusetts & $-2,928,768$ & $-15,800,000$ & $-238,464$ & $-238,464$ \\
Minnesota & 658,224 & $-4,595,376$ & $3,898,380$ & $2,039,580$ \\
New Hampshire & $1,022,880$ & $-429,168$ & $-3,120$ & $-3,120$ \\
New Jersey & $-3,582,240$ & $-18,300,000$ & $-835,240$ & $-835,240$ \\
New York & $-11,400,000$ & $-39,300,000$ & $15,800,000$ & $10,800,000$ \\
Rhode Island & $-2,912,992$ & $-4,796,740$ & 74,309 & 74,309 \\
Vermont & $-929,622$ & $-1,669,719$ & 237,939 & 36,033 \\
Washington & $-4,971,712$ & $-13,900,000$ & & 0 \\
\hline Total & $-74,259,082$ & $-230,882,939$ & $-10,253,753$ & $-19,829,919$ \\
& & & & 0 \\
\hline
\end{tabular}


Table 8. State Income Tax Revenue Effects of Same-sex Marriage under Different Assumptions on Allocation of Children/Dependents

\begin{tabular}{|c|c|c|c|c|c|c|}
\hline \multirow[b]{2}{*}{ State } & \multicolumn{2}{|c|}{ Claiming Own Children } & \multicolumn{2}{|c|}{ Highest Earner Claims } & \multicolumn{2}{|c|}{ Lowest Earner Claims } \\
\hline & Minimizing & Standard & Minimizing & Standard & Minimizing & Standard \\
\hline Alabama & 195,223 & 277,522 & 176,112 & 248,390 & 158,421 & 244,589 \\
\hline Alaska & 0 & 0 & 0 & 0 & 0 & 0 \\
\hline Arizona & $-486,346$ & $-486,346$ & $-292,644$ & $-292,644$ & $-671,044$ & $-671,044$ \\
\hline Arkansas & $-249,962$ & $-376,142$ & $-191,887$ & $-318,068$ & $-340,859$ & $-467,039$ \\
\hline California & $-28,800,000$ & $-28,800,000$ & $-25,800,000$ & $-25,800,000$ & $-33,400,000$ & $-33,400,000$ \\
\hline Colorado & 603,156 & $-690,616$ & 604,676 & $-651,220$ & 651,300 & $-802,992$ \\
\hline Connecticut & $-83,164$ & $-83,164$ & $-33,904$ & $-33,904$ & 95,180 & 95,180 \\
\hline Delaware & $-40,324$ & $-40,324$ & $-40,324$ & $-40,324$ & $-40,550$ & $-40,550$ \\
\hline District of Columbia & 961,260 & 955,416 & 961,260 & 955,416 & 884,228 & 878,380 \\
\hline Florida & 0 & 0 & 0 & 0 & 0 & 0 \\
\hline Georgia & 557,100 & 810,872 & 688,416 & 994,016 & 161,316 & 361,752 \\
\hline Hawaii & $-1,065,178$ & $-1,065,178$ & $-1,047,788$ & $-1,047,788$ & $-1,060,412$ & $-1,060,412$ \\
\hline Idaho & $-142,175$ & $-142,175$ & $-105,242$ & $-105,242$ & $-187,648$ & $-187,648$ \\
\hline Illinois & $-607,348$ & $-607,348$ & $-576,060$ & $-576,060$ & $-650,876$ & $-650,876$ \\
\hline Indiana & 65,948 & 65,948 & $-18,566$ & $-18,566$ & 91,122 & 91,122 \\
\hline Iowa & 309,728 & 62,986 & 183,492 & 9,846 & 314,671 & 55,698 \\
\hline Kansas & 263,577 & $-19,643$ & 271,179 & $-3,237$ & 557,080 & 234,554 \\
\hline Kentucky & $-200,854$ & $-200,854$ & $-191,814$ & $-191,814$ & $-189,232$ & $-189,232$ \\
\hline Louisiana & $-295,318$ & $-801,569$ & $-383,061$ & $-850,178$ & $-292,955$ & $-808,877$ \\
\hline Maine & $-74,390$ & $-455,932$ & $-74,390$ & $-455,932$ & $-289,048$ & $-738,768$ \\
\hline Maryland & 569,964 & $-23,440$ & 387,612 & $-94,556$ & 612,944 & $-51,712$ \\
\hline Massachusetts & $-238,464$ & $-238,464$ & $-287,808$ & $-287,808$ & $-744,528$ & $-744,528$ \\
\hline Michigan & $-481,736$ & $-481,736$ & $-517,748$ & $-517,748$ & $-389,636$ & $-389,636$ \\
\hline Minnesota & $3,898,380$ & $2,039,580$ & $3,801,680$ & $1,968,364$ & $3,628,100$ & $1,648,024$ \\
\hline Mississippi & $-77,298$ & $-85,463$ & $-54,796$ & $-62,961$ & $-118,043$ & $-126,958$ \\
\hline Missouri & 280,680 & $-496,160$ & 226,652 & $-467,330$ & 214,390 & $-595,488$ \\
\hline Montana & $-227,573$ & $-233,290$ & $-227,573$ & $-233,290$ & $-227,573$ & $-233,290$ \\
\hline Nebraska & 272,943 & 97,502 & 271,702 & 130,668 & 347,845 & 79,452 \\
\hline Nevada & 0 & 0 & 0 & 0 & 0 & 0 \\
\hline New Hampshire & $-3,120$ & $-3,120$ & $-3,120$ & $-3,120$ & $-3,120$ & $-3,120$ \\
\hline New Jersey & $-835,240$ & $-835,240$ & $-503,240$ & $-503,240$ & $-2,161,616$ & $-2,161,616$ \\
\hline New Mexico & 745,883 & 344,481 & 801,825 & 415,770 & 655,430 & 184,056 \\
\hline New York & $15,800,000$ & $10,800,000$ & $16,700,000$ & $12,000,000$ & $16,200,000$ & $11,600,000$ \\
\hline North Carolina & $-513,688$ & $-2,270,992$ & $-125,816$ & $-1,744,664$ & $-823,592$ & $-2,724,888$ \\
\hline North Dakota & $-56,802$ & $-56,802$ & $-42,161$ & $-42,161$ & $-80,731$ & $-81,103$ \\
\hline Ohio & $4,933,772$ & $4,933,772$ & $5,044,704$ & $5,044,704$ & $4,836,852$ & $4,836,852$ \\
\hline Oklahoma & 509,476 & 103,972 & 536,996 & 185,312 & 412,308 & $-48,650$ \\
\hline Oregon & 726,684 & 905,640 & 721,904 & 919,416 & 546,128 & 750,084 \\
\hline Pennsylvania & $-1,109,220$ & $-1,109,220$ & $-472,500$ & $-472,500$ & $-1,063,332$ & $-1,063,332$ \\
\hline Rhode Island & 74,309 & 74,309 & 47,813 & 47,813 & 31,166 & 31,166 \\
\hline South Carolina & 328,461 & $-77,808$ & 389,533 & $-16,736$ & 78,852 & $-343,621$ \\
\hline South Dakota & 0 & 0 & 0 & 0 & 0 & 0 \\
\hline Tennessee & $-63,738$ & $-63,738$ & $-63,738$ & $-63,738$ & $-63,738$ & $-63,738$ \\
\hline Texas & 0 & 0 & 0 & 0 & 0 & 0 \\
\hline Utah & 595,347 & 161,259 & 621,176 & 161,259 & 641,716 & 222,564 \\
\hline Vermont & 237,939 & 36,033 & 199,083 & 58,730 & 237,939 & 36,033 \\
\hline Virginia & 220,460 & $-946,988$ & 220,128 & $-947,312$ & 296,756 & $-891,804$ \\
\hline Washington & 0 & 0 & 0 & 0 & 0 & 0 \\
\hline West Virginia & 569,650 & 569,650 & 569,650 & 569,650 & 597,893 & 597,893 \\
\hline Wisconsin & 281,142 & 328,654 & 343,888 & 391,400 & 208,606 & 256,118 \\
\hline Wyoming & 0 & 0 & 0 & 0 & 0 & 0 \\
\hline Total & $-2,641,152$ & $-18,124,157$ & $2,719,616$ & $-11,741,387$ & $-10,300,000$ & $-26,337,406$ \\
\hline
\end{tabular}


Table 9. Federal Income Tax Revenue Effects of Same-sex Marriage under Different Assumptions Regarding Allocation of Children/Dependents

\begin{tabular}{|c|c|c|c|c|c|c|}
\hline \multirow[b]{2}{*}{ State } & \multicolumn{2}{|c|}{ Claiming Own Children } & \multicolumn{2}{|c|}{$\begin{array}{c}\text { Highest Earner Claims } \\
\text { Dependents }\end{array}$} & \multicolumn{2}{|c|}{$\begin{array}{c}\text { Lowest Earner Claims } \\
\text { Dependents }\end{array}$} \\
\hline & Minimizing & Standard & Minimizing & Standard & Minimizing & Standard \\
\hline Alabama & $-1,925,428$ & $-3,542,764$ & $-1,771,828$ & $-3,188,728$ & $-2,318,088$ & $-4,012,808$ \\
\hline Alaska & $-118,206$ & $-722,862$ & 116,280 & $-488,374$ & $-118,206$ & $-722,862$ \\
\hline Arizona & $-2,427,408$ & $-9,595,008$ & $-1,070,112$ & $-7,812,176$ & $-3,806,800$ & $-11,400,000$ \\
\hline Arkansas & 164,774 & $-827,388$ & 208,956 & $-719,424$ & $-455,072$ & $-1,441,352$ \\
\hline California & $-32,000,000$ & $-83,000,000$ & $-30,000,000$ & $-73,900,000$ & $-40,100,000$ & $-97,600,000$ \\
\hline Colorado & $-4,129,296$ & $-9,251,248$ & $-3,840,576$ & $-8,775,872$ & $-5,873,200$ & $-11,900,000$ \\
\hline Connecticut & $-4,305,520$ & $-7,930,496$ & $-2,802,960$ & $-5,757,792$ & $-4,780,544$ & $-9,643,392$ \\
\hline Delaware & 963,750 & 324,838 & 850,040 & 311,138 & $1,337,874$ & 573,202 \\
\hline District of Columbia & $3,064,528$ & 945,248 & $2,961,288$ & 895,672 & $3,064,528$ & 945,248 \\
\hline Florida & $-17,500,000$ & $-35,500,000$ & $-14,500,000$ & $-31,000,000$ & $-22,200,000$ & $-41,200,000$ \\
\hline Georgia & $-8,767,408$ & $-15,200,000$ & $-7,148,448$ & $-12,800,000$ & $-11,600,000$ & $-18,900,000$ \\
\hline Hawaii & 173,680 & $-906,632$ & 470,520 & $-345,896$ & $-6,560$ & $-1,086,872$ \\
\hline Idaho & $-1,098,504$ & $-1,489,606$ & $-979,219$ & $-1,291,072$ & $-1,252,199$ & $-1,643,301$ \\
\hline Illinois & $-6,414,144$ & $-18,100,000$ & $-6,018,464$ & $-16,500,000$ & $-8,934,272$ & $-21,500,000$ \\
\hline Indiana & $-2,524,944$ & $-5,942,984$ & $-1,437,792$ & $-4,274,928$ & $-4,029,848$ & $-8,226,672$ \\
\hline Iowa & $-1,225,226$ & $-2,978,886$ & $-1,106,894$ & $-2,161,714$ & $-1,624,210$ & $-3,378,814$ \\
\hline Kansas & $-1,180,680$ & $-2,404,718$ & $-1,116,284$ & $-2,232,502$ & $-2,876,266$ & $-4,255,318$ \\
\hline Kentucky & $-2,412,296$ & $-4,179,404$ & $-2,536,344$ & $-4,263,764$ & $-4,040,588$ & $-6,354,832$ \\
\hline Louisiana & $-4,116,500$ & $-6,920,320$ & $-3,263,772$ & $-5,814,080$ & $-4,874,452$ & $-7,756,256$ \\
\hline Maine & $-2,072,496$ & $-3,997,256$ & $-2,072,496$ & $-3,997,256$ & $-2,790,728$ & $-5,776,404$ \\
\hline Maryland & $-205,600$ & $-6,252,256$ & $-258,336$ & $-5,103,296$ & $-3,335,056$ & $-10,100,000$ \\
\hline Massachusetts & $-2,928,768$ & $-15,800,000$ & $-1,622,176$ & $-13,200,000$ & $-5,227,328$ & $-20,700,000$ \\
\hline Michigan & $-2,343,104$ & $-8,312,496$ & $-2,193,280$ & $-6,448,512$ & 278,848 & $-6,235,888$ \\
\hline Minnesota & 658,224 & $-4,595,376$ & 748,688 & $-4,440,080$ & $1,104,112$ & $-4,823,056$ \\
\hline Mississippi & $-1,793,834$ & $-2,334,486$ & $-1,605,544$ & $-2,126,666$ & $-2,990,526$ & $-3,587,040$ \\
\hline Missouri & $-3,985,984$ & $-8,513,048$ & $-3,476,272$ & $-7,319,616$ & $-5,483,456$ & $-10,100,000$ \\
\hline Montana & $-904,150$ & $-1,089,525$ & $-904,150$ & $-1,089,525$ & $-904,150$ & $-1,089,525$ \\
\hline Nebraska & $-32,888$ & $-243,682$ & 16,122 & $-51,726$ & 400,636 & $-205,328$ \\
\hline Nevada & $-1,113,416$ & $-4,115,948$ & $-231,728$ & $-3,085,232$ & $-1,884,716$ & $-5,114,272$ \\
\hline New Hampshire & $1,022,880$ & $-429,168$ & $1,132,436$ & $-313,692$ & 880,524 & $-748,412$ \\
\hline New Jersey & $-3,582,240$ & $-18,300,000$ & $-2,313,184$ & $-15,900,000$ & $-5,837,488$ & $-22,400,000$ \\
\hline New Mexico & $-3,315,892$ & $-5,207,072$ & $-2,980,720$ & $-4,761,484$ & $-4,156,032$ & $-6,704,376$ \\
\hline New York & $-11,400,000$ & $-39,300,000$ & $-7,707,136$ & $-33,400,000$ & $-14,200,000$ & $-47,300,000$ \\
\hline North Carolina & $-9,638,480$ & $-16,900,000$ & $-7,016,640$ & $-13,600,000$ & $-12,400,000$ & $-20,600,000$ \\
\hline North Dakota & $-660,441$ & $-660,441$ & $-323,086$ & $-323,086$ & $-962,519$ & $-965,233$ \\
\hline Ohio & $-10,800,000$ & $-17,700,000$ & $-8,873,632$ & $-15,300,000$ & $-12,400,000$ & $-19,900,000$ \\
\hline Oklahoma & $-359,624$ & $-1,994,060$ & 172,044 & $-1,226,460$ & $-551,100$ & $-2,528,588$ \\
\hline Oregon & $-6,168,344$ & $-8,806,512$ & $-5,940,256$ & $-8,428,344$ & $-6,036,264$ & $-9,709,648$ \\
\hline Pennsylvania & $-5,311,520$ & $-18,200,000$ & $-3,079,072$ & $-15,400,000$ & $-7,382,848$ & $-21,100,000$ \\
\hline Rhode Island & $-2,912,992$ & $-4,796,740$ & $-2,937,592$ & $-4,706,168$ & $-2,881,184$ & $-5,004,568$ \\
\hline South Carolina & $-3,211,672$ & $-4,674,848$ & $-2,858,000$ & $-4,321,180$ & $-4,136,660$ & $-5,703,008$ \\
\hline South Dakota & $-301,292$ & $-415,290$ & $-282,070$ & $-278,942$ & $-341,942$ & $-455,940$ \\
\hline Tennessee & $-6,858,224$ & $-9,798,384$ & $-5,322,936$ & $-8,159,512$ & $-9,091,024$ & $-12,500,000$ \\
\hline Texas & $-9,945,216$ & $-31,800,000$ & $-7,108,608$ & $-27,100,000$ & $-18,000,000$ & $-42,300,000$ \\
\hline Utah & $-2,551,866$ & $-4,485,316$ & $-1,940,782$ & $-3,738,600$ & $-3,572,504$ & $-6,169,084$ \\
\hline Vermont & $-929,622$ & $-1,669,719$ & $-413,921$ & $-942,105$ & $-929,622$ & $-1,669,719$ \\
\hline Virginia & $-6,056,560$ & $-11,400,000$ & $-5,736,656$ & $-10,900,000$ & $-9,587,552$ & $-16,000,000$ \\
\hline Washington & $-4,971,712$ & $-13,900,000$ & $-2,676,656$ & $-11,000,000$ & $-8,060,016$ & $-17,600,000$ \\
\hline West Virginia & $-449,767$ & $-1,509,341$ & $-491,732$ & $-1,454,341$ & $-488,761$ & $-1,568,971$ \\
\hline Wisconsin & $1,919,272$ & $-1,101,624$ & $2,455,448$ & $-240,496$ & $1,538,824$ & $-1,579,512$ \\
\hline Wyoming & $-169,146$ & $-172,981$ & $-169,146$ & $-172,981$ & $-169,146$ & $-172,981$ \\
\hline Total & $-187,153,302$ & $-475,697,799$ & $-149,041,152$ & $-408,601,088$ & $-254,085,581$ & $-579,915,582$ \\
\hline
\end{tabular}


Table 10. Summary Statistics of Federal and State Marriage Tax/Subsidy

\begin{tabular}{|c|c|c|c|c|c|c|c|c|}
\hline \multirow[b]{2}{*}{ State } & \multicolumn{4}{|c|}{ Federal Marriage Tax/Subsidy by State } & \multicolumn{4}{|c|}{ State Marriage Tax/Subsidy by State } \\
\hline & $\begin{array}{c}\text { Weighted } \\
\text { Mean }\end{array}$ & $\begin{array}{l}\text { Standard } \\
\text { Deviation }\end{array}$ & Minimum & Maximum & $\begin{array}{c}\text { Weighted } \\
\text { Mean }\end{array}$ & $\begin{array}{c}\text { Standard } \\
\text { Deviation }\end{array}$ & Minimum & Maximum \\
\hline Alabama & -353.1 & $1,314.7$ & $-7,468.4$ & $2,994.8$ & 35.8 & 125.0 & -252.8 & 388.5 \\
\hline Alaska & -99.8 & $2,622.7$ & $-9,116.3$ & $3,830.2$ & 0.0 & 0.0 & 0.0 & 0.0 \\
\hline Arizona & -159.6 & $1,970.0$ & $-8,670.0$ & $9,135.9$ & -32.0 & 201.6 & $-1,204.8$ & 427.8 \\
\hline Arkansas & 41.4 & $2,434.0$ & $-4,790.0$ & $12,643.0$ & -62.9 & 209.5 & -479.5 & 371.7 \\
\hline California & -359.5 & $3,069.7$ & $-12,906.6$ & $13,745.4$ & -322.9 & 903.6 & $-4,161.4$ & $2,004.7$ \\
\hline Colorado & -333.0 & $1,867.6$ & $-7,335.0$ & $9,272.1$ & 48.6 & 247.0 & $-1,549.9$ & 388.9 \\
\hline Connecticut & $1,048.8$ & $4,163.8$ & $-7,533.3$ & $14,115.0$ & -9.4 & 576.2 & $-3,035.0$ & $1,050.0$ \\
\hline Delaware & -486.3 & $3,744.4$ & $-18,963.6$ & $11,892.3$ & -22.5 & 279.6 & -787.7 & 271.1 \\
\hline District of Columbia & 538.7 & $1,597.0$ & $-2,981.0$ & $4,286.1$ & 329.0 & 200.8 & -258.8 & 990.0 \\
\hline Florida & -435.2 & $2,248.4$ & $-11,745.4$ & $12,904.5$ & 0.0 & 0.0 & 0.0 & 0.0 \\
\hline Georgia & -541.1 & $2,001.8$ & $-12,930.0$ & $5,308.0$ & 34.4 & 330.3 & $-3,384.0$ & 522.3 \\
\hline Hawaii & 62.2 & $5,470.3$ & $-17,830.6$ & $10,489.5$ & -381.2 & $1,122.1$ & $-5,724.1$ & 359.5 \\
\hline Idaho & -602.6 & $1,378.9$ & $-5,624.5$ & 431.3 & -78.0 & 469.6 & $-1,942.5$ & 386.1 \\
\hline Illinois & -316.5 & $2,456.1$ & $-9,495.7$ & $9,300.8$ & -30.0 & 124.6 & $-1,200.0$ & 182.8 \\
\hline Indiana & -238.1 & $1,890.6$ & $-6,890.0$ & $6,167.6$ & 6.2 & 106.9 & -428.7 & 453.2 \\
\hline Iowa & -257.1 & $2,051.4$ & $-7,682.5$ & $3,956.1$ & 65.0 & 208.1 & $-1,343.9$ & 490.9 \\
\hline Kansas & -290.6 & 885.1 & $-3,084.0$ & $2,668.6$ & 64.9 & 385.1 & -816.6 & 954.6 \\
\hline Kentucky & -315.0 & $1,766.0$ & $-11,486.5$ & $4,432.6$ & -26.2 & 345.1 & $-3,075.8$ & 418.8 \\
\hline Louisiana & -669.5 & $2,426.8$ & $-8,925.0$ & $6,283.8$ & -48.0 & 187.0 & -845.7 & 237.0 \\
\hline Maine & -465.3 & $1,317.9$ & $-5,824.9$ & $2,908.1$ & -16.7 & 496.2 & $-1,531.0$ & 994.5 \\
\hline Maryland & -19.5 & $2,870.5$ & $-9,493.8$ & $12,152.5$ & 53.9 & 311.1 & $-1,714.8$ & $1,304.2$ \\
\hline Massachusetts & -138.7 & $2,617.7$ & $-12,687.2$ & $15,020.5$ & -11.3 & 242.6 & $-1,584.7$ & 665.0 \\
\hline Michigan & -163.1 & $2,190.4$ & $-9,625.0$ & $8,984.7$ & -33.5 & 266.5 & $-1,735.7$ & $1,152.0$ \\
\hline Minnesota & 54.7 & $1,879.8$ & $-5,358.6$ & $9,908.5$ & 324.2 & 509.2 & -924.7 & $2,355.0$ \\
\hline Mississippi & -734.9 & $2,398.4$ & $-9,016.0$ & $5,775.3$ & -31.7 & 188.6 & -519.0 & 215.0 \\
\hline Missouri & -376.2 & $1,935.9$ & $-9,625.0$ & $10,932.6$ & 26.5 & 332.0 & $-1,245.0$ & $1,859.0$ \\
\hline Montana & -621.8 & $1,798.7$ & $-11,142.9$ & 844.6 & -156.5 & 624.9 & $-3,750.7$ & 174.3 \\
\hline Nebraska & -12.0 & $1,894.4$ & $-3,522.0$ & $6,693.7$ & 99.6 & 393.8 & -763.0 & $1,145.7$ \\
\hline Nevada & -181.3 & $1,768.6$ & $-8,403.8$ & $3,832.1$ & 0.0 & 0.0 & 0.0 & 0.0 \\
\hline New Hampshire & 320.1 & $1,991.3$ & $-9,817.0$ & $8,595.1$ & -1.0 & 10.8 & -120.0 & 0.0 \\
\hline New Jersey & -228.8 & $2,577.0$ & $-13,168.8$ & $8,236.3$ & -53.4 & 614.8 & $-2,339.0$ & $1,492.5$ \\
\hline New Mexico & -592.9 & $1,986.2$ & $-8,971.1$ & $4,850.9$ & 133.4 & 320.4 & -799.0 & 703.2 \\
\hline New York & -268.5 & $3,202.5$ & $-17,864.6$ & $14,178.5$ & 372.8 & $1,515.1$ & $-4,589.5$ & $12,579.0$ \\
\hline North Carolina & -564.2 & $2,062.9$ & $-6,090.7$ & $9,483.9$ & -30.1 & 387.6 & $-2,197.5$ & 749.5 \\
\hline North Dakota & -632.0 & $1,006.2$ & $-3,147.5$ & 0.0 & -54.4 & 63.0 & -164.7 & 0.0 \\
\hline Ohio & -618.1 & $2,374.9$ & $-16,842.8$ & $4,331.3$ & 281.8 & 446.2 & $-1,708.3$ & $1,676.0$ \\
\hline Oklahoma & -69.2 & $1,072.1$ & $-3,386.3$ & $1,931.3$ & 98.1 & 299.9 & -749.0 & 902.5 \\
\hline Oregon & -687.7 & $2,127.2$ & $-10,065.0$ & $4,106.4$ & 81.0 & 630.4 & $-4,313.6$ & $1,458.4$ \\
\hline Pennsylvania & -236.4 & $1,934.5$ & $-8,275.5$ & $8,836.3$ & -49.4 & 193.8 & $-1,074.5$ & 184.2 \\
\hline Rhode Island & -820.8 & $1,972.4$ & $-9,625.0$ & $2,424.6$ & 20.9 & 512.4 & $-1,266.0$ & $1,145.8$ \\
\hline South Carolina & -595.2 & $1,743.0$ & $-6,132.7$ & $4,431.3$ & 60.9 & 355.2 & -654.5 & 713.6 \\
\hline South Dakota & -471.5 & 801.4 & $-1,378.8$ & 505.9 & 0.0 & 0.0 & 0.0 & 0.0 \\
\hline Tennessee & -766.3 & $2,019.7$ & $-10,263.8$ & $3,135.2$ & -7.1 & 20.7 & -75.0 & 0.0 \\
\hline Texas & -232.1 & $2,302.0$ & $-14,438.1$ & $11,056.0$ & 0.0 & 0.0 & 0.0 & 0.0 \\
\hline Utah & -617.7 & $2,109.4$ & $-8,420.2$ & $5,221.9$ & 144.1 & 310.2 & -669.2 & 892.5 \\
\hline Vermont & -432.2 & $2,182.7$ & $-9,408.7$ & $9,555.1$ & 110.6 & 530.2 & $-2,136.5$ & $1,408.1$ \\
\hline Virginia & -509.1 & $2,099.5$ & $-6,919.1$ & $9,915.6$ & 18.5 & 215.2 & $-1,249.5$ & 477.6 \\
\hline Washington & -301.1 & $1,967.9$ & $-9,499.4$ & $4,269.3$ & 0.0 & 0.0 & 0.0 & 0.0 \\
\hline West Virginia & -255.0 & $1,638.1$ & $-4,291.5$ & $4,431.3$ & 322.9 & 541.8 & $-1,111.5$ & $1,125.0$ \\
\hline Wisconsin & 225.7 & $1,611.2$ & $-4,294.8$ & $7,532.0$ & 33.1 & 403.2 & $-1,235.9$ & $1,709.7$ \\
\hline Wyoming & $-1,331.9$ & 112.4 & $-1,528.8$ & $-1,187.0$ & 0.0 & 0.0 & 0.0 & 0.0 \\
\hline
\end{tabular}


Table 11. Income Tax Revenue Effects of Same-sex Marriage Assuming that Couples with Marriage Tax Greater than \$5,000 Do Not Marry

\begin{tabular}{|c|c|c|c|}
\hline State & $\begin{array}{l}\text { Federal Marriage Tax } \\
\text { for 95th Percentile }\end{array}$ & $\begin{array}{c}\text { Federal Revenue } \\
\text { Increase/Decrease }\end{array}$ & $\begin{array}{c}\text { State Revenue } \\
\text { Increase/Decrease }\end{array}$ \\
\hline Alabama & 1,138 & $-1,925,427$ & 195,223 \\
\hline Alaska & 3,830 & $-118,207$ & 0 \\
\hline Arizona & 1,992 & $-4,256,205$ & $-471,370$ \\
\hline Arkansas & 1,931 & $-1,327,106$ & $-249,961$ \\
\hline California & 4,194 & $-68,400,000$ & $-30,800,000$ \\
\hline Colorado & 1,257 & $-5,375,852$ & 587,851 \\
\hline Connecticut & 3,119 & $-7,451,403$ & 63,310 \\
\hline Delaware & 4,286 & 963,749 & $-40,324$ \\
\hline District of Columbia & 11,296 & $-852,308$ & 799,331 \\
\hline Florida & 2,044 & $-23,400,000$ & 0 \\
\hline Georgia & 1,502 & $-9,192,033$ & 548,000 \\
\hline Hawaii & 10,489 & $-4,014,969$ & $-1,074,058$ \\
\hline Idaho & 256 & $-1,098,504$ & $-142,175$ \\
\hline Illinois & 3,258 & $-9,864,439$ & $-607,349$ \\
\hline Indiana & 2,038 & $-4,031,914$ & 65,949 \\
\hline Iowa & 3,744 & $-1,225,228$ & 309,728 \\
\hline Kansas & 773 & $-1,180,680$ & 263,577 \\
\hline Kentucky & 1,042 & $-2,412,298$ & $-200,854$ \\
\hline Louisiana & 1,524 & $-4,594,065$ & $-276,207$ \\
\hline Maine & 675 & $-2,072,495$ & $-74,390$ \\
\hline Maryland & 4,678 & $-4,055,935$ & 335,664 \\
\hline Massachusetts & 2,639 & $-8,095,727$ & $-228,518$ \\
\hline Michigan & 4,131 & $-4,357,306$ & $-481,736$ \\
\hline Minnesota & 2,265 & $-897,425$ & $3,828,098$ \\
\hline Mississippi & 600 & $-2,140,350$ & $-86,598$ \\
\hline Missouri & 895 & $-5,144,843$ & 300,057 \\
\hline Montana & 845 & $-904,150$ & $-227,573$ \\
\hline Nebraska & 6,694 & $-1,130,660$ & 85,053 \\
\hline Nevada & 2,155 & $-1,113,419$ & 0 \\
\hline New Hampshire & 2,359 & 300,888 & $-3,120$ \\
\hline New Jersey & 3,728 & $-5,712,219$ & $-946,291$ \\
\hline New Mexico & 1,501 & $-3,315,889$ & 745,883 \\
\hline New York & 5,601 & $-31,300,000$ & $5,355,809$ \\
\hline North Carolina & 972 & $-12,500,000$ & $-679,842$ \\
\hline North Dakota & 0 & $-660,441$ & $-56,802$ \\
\hline Ohio & 989 & $-10,800,000$ & $4,933,772$ \\
\hline Oklahoma & 1,931 & $-359,622$ & 509,476 \\
\hline Oregon & 2,494 & $-6,168,349$ & 726,684 \\
\hline Pennsylvania & 1,733 & $-6,559,777$ & $-1,109,222$ \\
\hline Rhode Island & 757 & $-2,912,993$ & 74,309 \\
\hline South Carolina & 1,684 & $-3,211,670$ & 328,461 \\
\hline South Dakota & 506 & $-301,292$ & 0 \\
\hline Tennessee & 1,487 & $-6,858,221$ & $-63,738$ \\
\hline Texas & 2,276 & $-16,400,000$ & 0 \\
\hline Utah & 1,190 & $-2,880,848$ & 589,323 \\
\hline Vermont & 1,829 & $-1,388,267$ & 170,350 \\
\hline Virginia & 1,158 & $-7,987,146$ & 208,759 \\
\hline Washington & 2,305 & $-4,971,709$ & 0 \\
\hline West Virginia & 3,086 & $-449,767$ & 569,650 \\
\hline Wisconsin & 2,368 & 721,685 & 440,397 \\
\hline Wyoming & $-1,187$ & $-169,146$ & 0 \\
\hline Total & & $-303,508,672$ & $-15,785,414$ \\
\hline
\end{tabular}


Table 12. Estimated Number of Same-Sex Couple Households from Different Data Sources

\begin{tabular}{|c|c|c|c|}
\hline State & $\begin{array}{c}\text { Census } 2010 \\
\text { Corrected Totoals }\end{array}$ & $\begin{array}{c}\text { ACS } 2010 \text { Weighted } \\
\text { Totals }^{(a)}\end{array}$ & $\begin{array}{c}\text { ACS } 2010 \text { Weighted } \\
\text { without Allocated } \\
\text { Status }^{(b)} \\
\end{array}$ \\
\hline Alabama & 6,582 & 5,453 & 2,906 \\
\hline Alaska & 1,228 & 1,185 & 705 \\
\hline Arizona & 15,817 & 15,210 & 11,800 \\
\hline Arkansas & 4,226 & 3,977 & 2,226 \\
\hline California & 98,153 & 89,115 & 56,121 \\
\hline Colorado & 12,424 & 12,401 & 9,159 \\
\hline Connecticut & 7,852 & 8,853 & 4,966 \\
\hline Delaware & 2,646 & 1,789 & 1,103 \\
\hline District of Columbia & 4,822 & 2,922 & 2,707 \\
\hline Florida & 48,496 & 40,281 & 29,428 \\
\hline Georgia & 21,318 & 16,202 & 11,227 \\
\hline Hawaii & 3,239 & 2,794 & 1,417 \\
\hline Idaho & 2,042 & 1,823 & 1,090 \\
\hline Illinois & 23,049 & 20,265 & 13,804 \\
\hline Indiana & 11,074 & 10,604 & 8,543 \\
\hline Iowa & 4,093 & 4,766 & 2,816 \\
\hline Kansas & 4,009 & 4,063 & 3,352 \\
\hline Kentucky & 7,195 & 7,657 & 5,276 \\
\hline Louisiana & 8,076 & 6,149 & 4,468 \\
\hline Maine & 3,958 & 4,454 & 3,334 \\
\hline Maryland & 12,538 & 10,565 & 7,302 \\
\hline Massa-chusetts & 20,256 & 21,123 & 10,524 \\
\hline Michigan & 14,598 & 14,367 & 10,311 \\
\hline Minnesota & 10,207 & 12,025 & 9,045 \\
\hline Mississippi & 3,484 & 2,441 & 1,442 \\
\hline Missouri & 10,557 & 10,596 & 8,549 \\
\hline Montana & 1,348 & 1,454 & 529 \\
\hline Nebraska & 2,356 & 2,740 & 1,776 \\
\hline Nevada & 7,140 & 6,140 & 4,417 \\
\hline New Hampshire & 3,260 & 3,195 & 1,464 \\
\hline New Jersey & 16,875 & 15,655 & 10,267 \\
\hline New Mexico & 5,825 & 5,593 & 4,528 \\
\hline New York & 48,932 & 42,326 & 29,421 \\
\hline North Carolina & 18,309 & 17,083 & 11,808 \\
\hline North Dakota & 559 & 1,045 & 564 \\
\hline Ohio & 19,684 & 17,508 & 13,806 \\
\hline Oklahoma & 6,134 & 5,194 & 3,887 \\
\hline Oregon & 11,773 & 8,970 & 6,492 \\
\hline Pennsylvania & 22,336 & 22,466 & 14,520 \\
\hline Rhode Island & 2,785 & 3,549 & 2,718 \\
\hline South Carolina & 7,214 & 5,396 & 3,794 \\
\hline South Dakota & 714 & 639 & 185 \\
\hline Tennessee & 10,898 & 8,950 & 6,921 \\
\hline Texas & 46,401 & 42,843 & 32,469 \\
\hline Utah & 3,909 & 4,131 & 2,893 \\
\hline Vermont & 2,143 & 2,151 & 1,176 \\
\hline Virginia & 14,243 & 11,897 & 7,462 \\
\hline Washington & 19,003 & 16,514 & 12,817 \\
\hline West Virginia & 2,848 & 1,764 & 1,160 \\
\hline Wisconsin & 9,179 & 8,505 & 6,343 \\
\hline Wyoming & 657 & 127 & 99 \\
\hline United States & 646,464 & 586,915 & 405,137 \\
\hline
\end{tabular}


Table 13. Estimated Income Tax Revenue Effects Using Each State's Average Marriage Tax/Subsidy and Number of Same-Sex Couples from Different Sources

\begin{tabular}{|c|c|c|c|c|c|c|}
\hline \multirow[b]{2}{*}{ State } & \multicolumn{3}{|c|}{ Federal Revenue } & \multicolumn{3}{|c|}{ State Revenue } \\
\hline & $\begin{array}{c}\text { Census } 2010 \\
\text { Corrected } \\
\text { Totals } \\
\end{array}$ & $\begin{array}{c}\text { ACS 2010 } \\
\text { Household } \\
\text { Weights } \\
\end{array}$ & $\begin{array}{c}\text { ACS } 2010 \\
\text { Weighted without }^{(\mathbf{a})} \\
\text { Allocated Status }^{(2)}\end{array}$ & $\begin{array}{c}\text { Census } 2010 \\
\text { Corrected } \\
\text { Totals } \\
\end{array}$ & $\begin{array}{c}\text { ACS 2010 } \\
\text { Household } \\
\text { Weights } \\
\end{array}$ & $\begin{array}{c}\text { ACS } 2010 \\
\text { Weighted without } \\
\text { Allocated Status }^{\text {(a) }}\end{array}$ \\
\hline Alabama & $-2,324,071$ & $-1,925,428$ & $-1,026,094$ & 235,643 & 195,223 & 104,038 \\
\hline Alaska & $-122,497$ & $-118,206$ & $-70,326$ & 0 & 0 & 0 \\
\hline Arizona & $-2,524,275$ & $-2,427,408$ & $-1,883,192$ & $-505,756$ & $-486,346$ & $-377,310$ \\
\hline Arkansas & 175,089 & 164,774 & 92,226 & $-265,612$ & $-249,962$ & $-139,908$ \\
\hline California & $-35,288,713$ & $-32,000,000$ & $-20,177,048$ & $-31,688,706$ & $-28,800,000$ & $-18,118,670$ \\
\hline Colorado & $-4,136,944$ & $-4,129,296$ & $-3,049,764$ & 604,277 & 603,156 & 445,474 \\
\hline Connecticut & $8,234,981$ & $-4,305,520$ & $5,208,217$ & $-73,761$ & $-83,164$ & $-46,650$ \\
\hline Delaware & $-1,286,842$ & 963,750 & $-536,428$ & $-59,641$ & $-40,324$ & $-24,862$ \\
\hline District of Columbia & $2,597,651$ & $3,064,528$ & $1,458,283$ & $1,586,312$ & 961,260 & 890,532 \\
\hline Florida & $-21,107,549$ & $-17,500,000$ & $-12,808,334$ & 0 & 0 & 0 \\
\hline Georgia & $-11,535,820$ & $-8,767,408$ & $-6,075,272$ & 733,009 & 557,100 & 386,035 \\
\hline Hawaii & 201,341 & 173,680 & 88,083 & $-1,234,829$ & $-1,065,178$ & $-540,214$ \\
\hline Idaho & $-1,230,469$ & $-1,098,504$ & $-656,813$ & $-159,255$ & $-142,175$ & $-85,009$ \\
\hline Illinois & $-7,295,320$ & $-6,414,144$ & $-4,369,152$ & $-690,786$ & $-607,348$ & $-413,711$ \\
\hline Indiana & $-2,636,861$ & $-2,524,944$ & $-2,034,198$ & 68,872 & 65,948 & 53,131 \\
\hline Iowa & $-1,052,215$ & $-1,225,226$ & $-723,928$ & 265,992 & 309,728 & 183,003 \\
\hline Kansas & $-1,164,988$ & $-1,180,680$ & $-974,068$ & 260,074 & 263,577 & 217,453 \\
\hline Kentucky & $-2,266,747$ & $-2,412,296$ & $-1,662,176$ & $-188,735$ & $-200,854$ & $-138,397$ \\
\hline Louisiana & $-5,406,546$ & $-4,116,500$ & $-2,991,140$ & $-387,866$ & $-295,318$ & $-214,585$ \\
\hline Maine & $-1,841,701$ & $-2,072,496$ & $-1,551,347$ & $-66,106$ & $-74,390$ & $-55,684$ \\
\hline Maryland & $-244,010$ & $-205,600$ & $-142,109$ & 676,406 & 569,964 & 393,932 \\
\hline Massa-chusetts & $-2,808,549$ & $-2,928,768$ & $-1,459,181$ & $-228,674$ & $-238,464$ & $-118,807$ \\
\hline Michigan & $-2,380,786$ & $-2,343,104$ & $-1,681,620$ & $-489,481$ & $-481,736$ & $-345,735$ \\
\hline Minnesota & 558,701 & 658,224 & 495,097 & $3,309,005$ & $3,898,380$ & $2,932,297$ \\
\hline Mississippi & $-2,560,311$ & $-1,793,834$ & $-1,059,693$ & $-110,326$ & $-77,298$ & $-45,663$ \\
\hline Missouri & $-3,971,317$ & $-3,985,984$ & $-3,215,951$ & 279,647 & 280,680 & 226,456 \\
\hline Montana & $-838,236$ & $-904,150$ & $-328,952$ & $-210,983$ & $-227,573$ & $-82,797$ \\
\hline Nebraska & $-28,280$ & $-32,888$ & $-21,318$ & 234,691 & 272,943 & 176,915 \\
\hline Nevada & $-1,294,758$ & $-1,113,416$ & $-800,973$ & 0 & 0 & 0 \\
\hline New Hampshire & $1,043,687$ & $1,022,880$ & 468,699 & $-3,183$ & $-3,120$ & $-1,430$ \\
\hline New Jersey & $-3,861,395$ & $-3,582,240$ & $-2,349,330$ & $-900,331$ & $-835,240$ & $-547,775$ \\
\hline New Mexico & $-3,453,433$ & $-3,315,892$ & $-2,684,489$ & 776,823 & 745,883 & 603,855 \\
\hline New York & $-13,137,293$ & $-11,400,000$ & $-7,898,968$ & $18,243,420$ & $15,800,000$ & $10,969,093$ \\
\hline North Carolina & $-10,330,214$ & $-9,638,480$ & $-6,662,252$ & $-550,559$ & $-513,688$ & $-355,072$ \\
\hline North Dakota & $-353,289$ & $-660,441$ & $-356,449$ & $-30,385$ & $-56,802$ & $-30,657$ \\
\hline Ohio & $-12,167,306$ & $-10,800,000$ & $-8,533,928$ & $5,546,971$ & $4,933,772$ & $3,890,545$ \\
\hline Oklahoma & $-424,705$ & $-359,624$ & $-269,128$ & 601,680 & 509,476 & 381,273 \\
\hline Oregon & $-8,095,872$ & $-6,168,344$ & $-4,464,317$ & 953,763 & 726,684 & 525,935 \\
\hline Pennsylvania & $-5,280,787$ & $-5,311,520$ & $-3,432,890$ & $-1,102,804$ & $-1,109,220$ & $-716,901$ \\
\hline Rhode Island & $-2,285,907$ & $-2,912,992$ & $-2,230,914$ & 58,312 & 74,309 & 56,910 \\
\hline South Carolina & $-4,293,734$ & $-3,211,672$ & $-2,258,168$ & 439,125 & 328,461 & 230,945 \\
\hline South Dakota & $-336,655$ & $-301,292$ & $-87,228$ & 0 & 0 & 0 \\
\hline Tennessee & $-8,350,938$ & $-6,858,224$ & $-5,303,436$ & $-77,611$ & $-63,738$ & $-49,288$ \\
\hline Texas & $-10,771,180$ & $-9,945,216$ & $-7,537,110$ & 0 & 0 & 0 \\
\hline Utah & $-2,414,729$ & $-2,551,866$ & $-1,787,110$ & 563,353 & 595,347 & 416,930 \\
\hline Vermont & $-926,164$ & $-929,622$ & $-508,245$ & 237,053 & 237,939 & 130,086 \\
\hline Virginia & $-7,250,868$ & $-6,056,560$ & $-3,798,777$ & 263,933 & 220,460 & 138,276 \\
\hline Washington & $-5,721,047$ & $-4,971,712$ & $-3,858,689$ & 0 & 0 & 0 \\
\hline West Virginia & $-726,155$ & $-449,767$ & $-295,765$ & 919,707 & 569,650 & 374,600 \\
\hline Wisconsin & $2,071,371$ & $1,919,272$ & $1,431,387$ & 303,422 & 281,142 & 209,675 \\
\hline Wyoming & $-875,032$ & $-169,146$ & $-131,854$ & 0 & 0 & 0 \\
\hline United States & $-201,521,685$ & $-187,153,302$ & $-124,506,127$ & $-1,863,901$ & $-2,641,152$ & $1,488,264$ \\
\hline
\end{tabular}


Figure 1. State Income Tax Revenue Effects of Same-sex Marriage Assuming Individuals Claim their Own Children and Minimize their Tax Liabilities
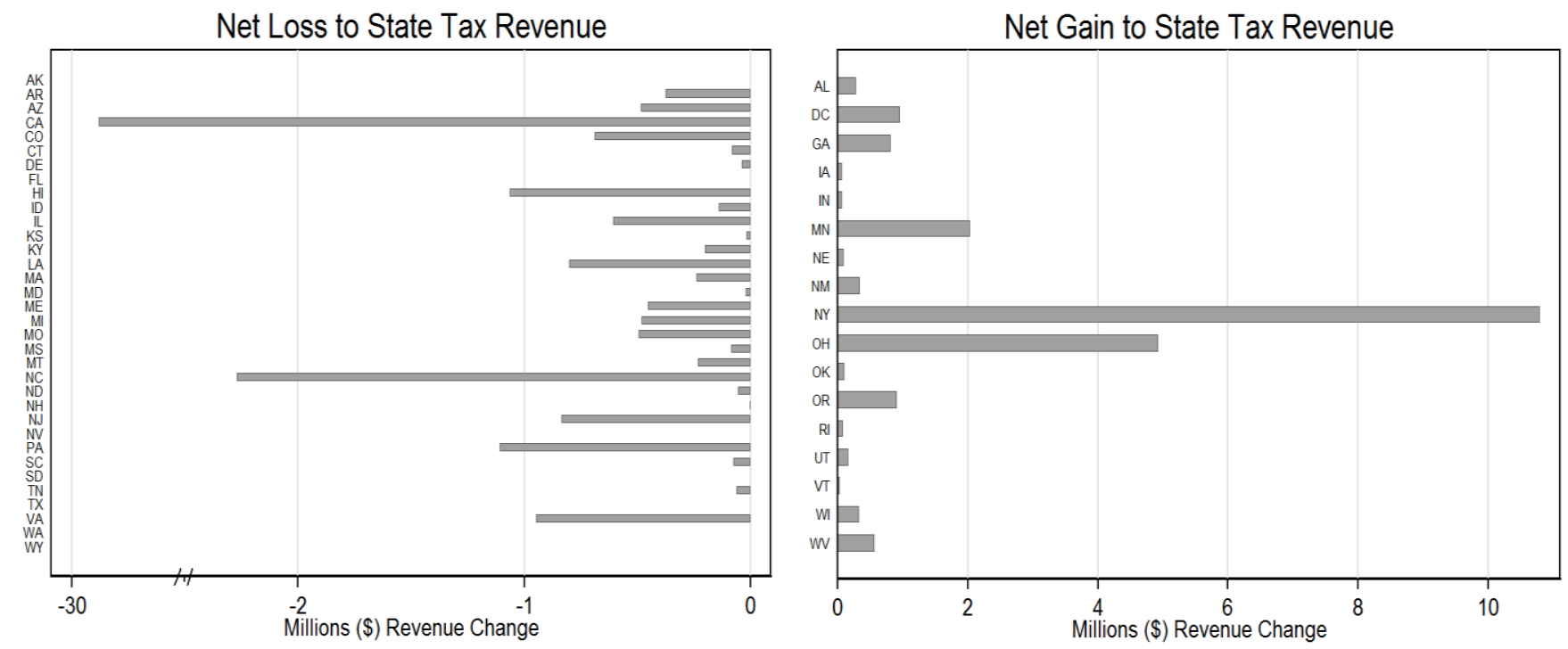

Figure 2. Federal Income Tax Revenue Effects of Same-sex Marriage Assuming Individuals Claim their Own Children and Minimize their Tax Liabilities
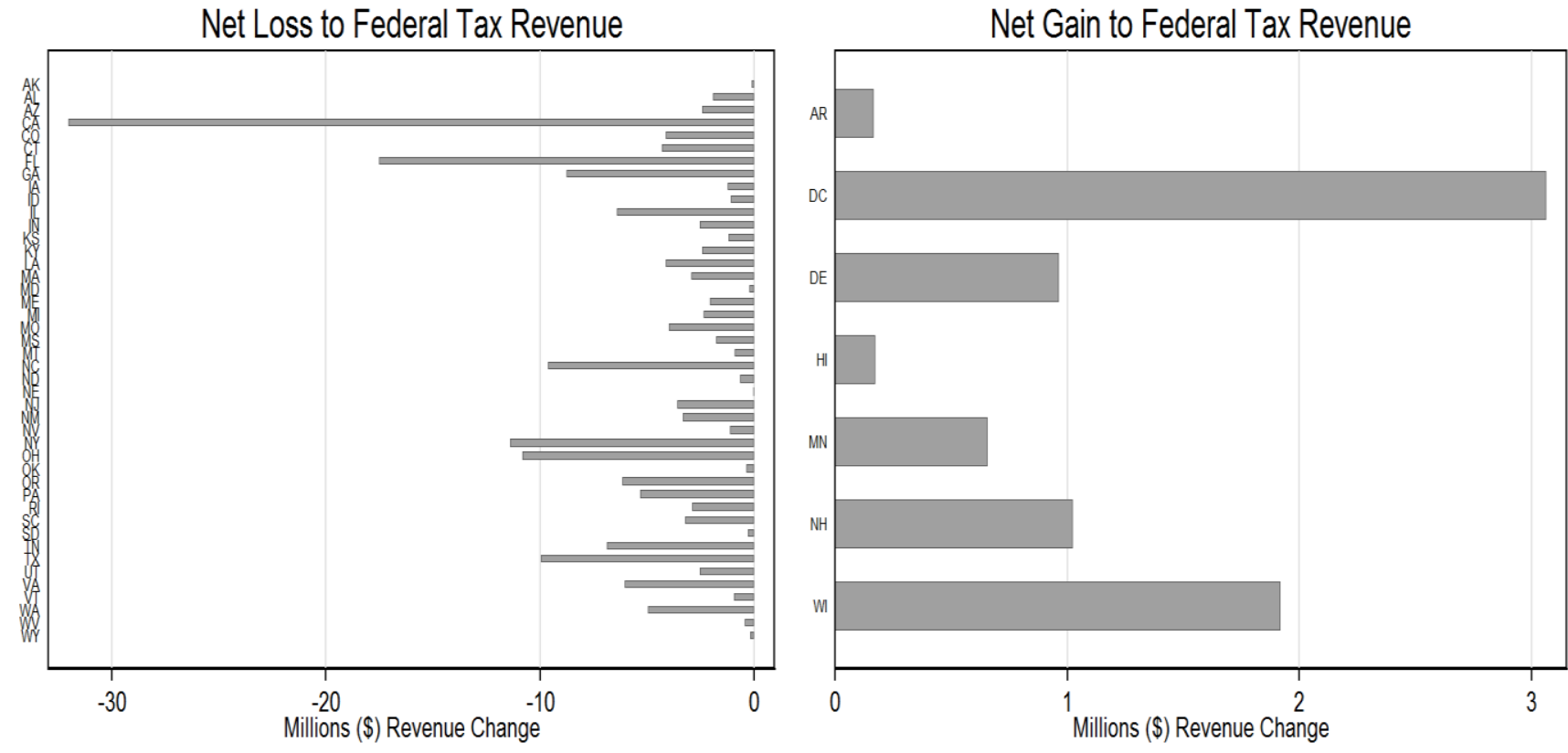
Figure 3. State Income Tax Revenue Effects of Same-sex Marriage Averaged Across Same-sex Couples

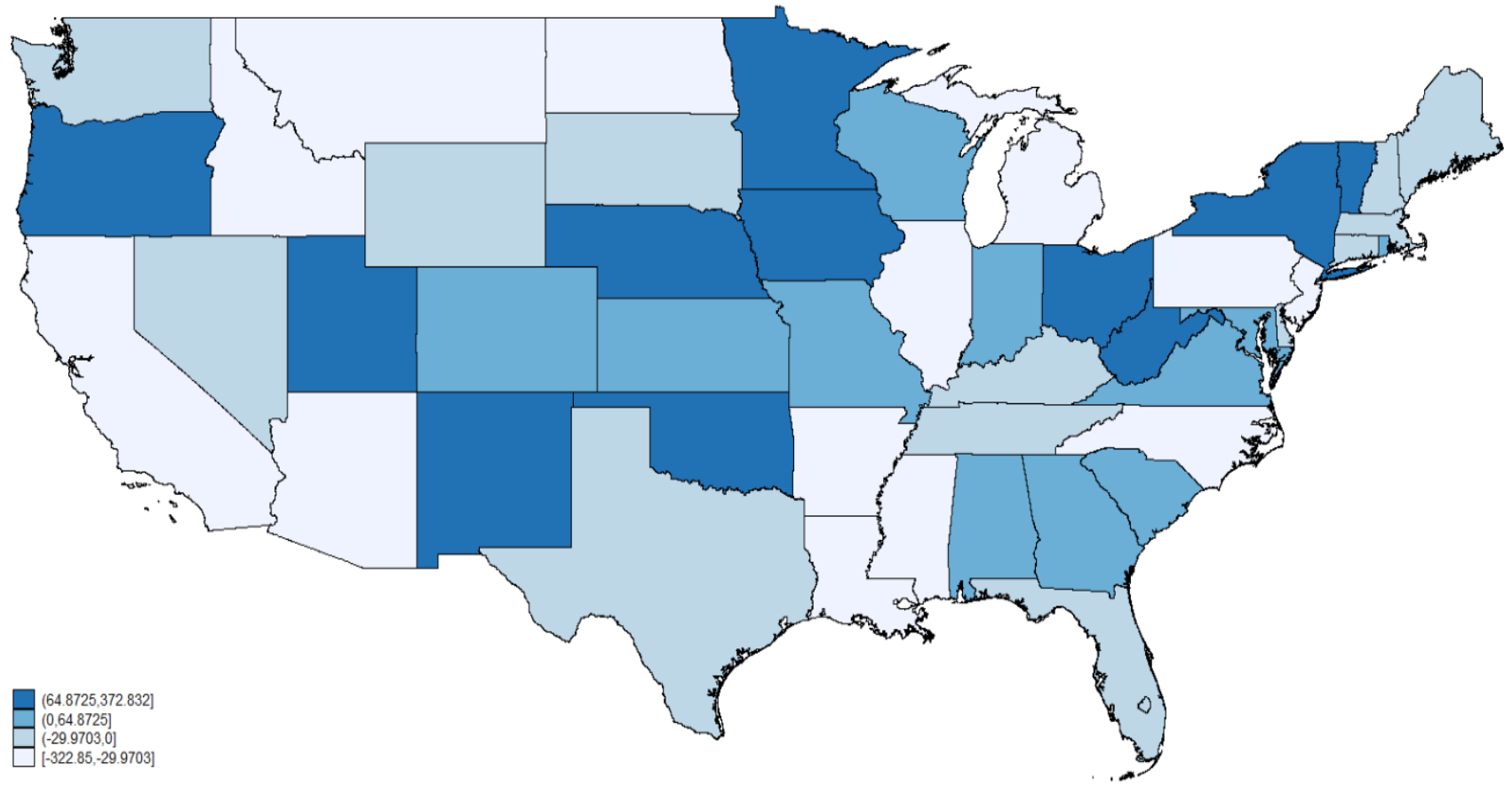

Figure 4. Federal Income Tax Revenue Effects of Same-sex Marriage Averaged Across Same-sex Couples

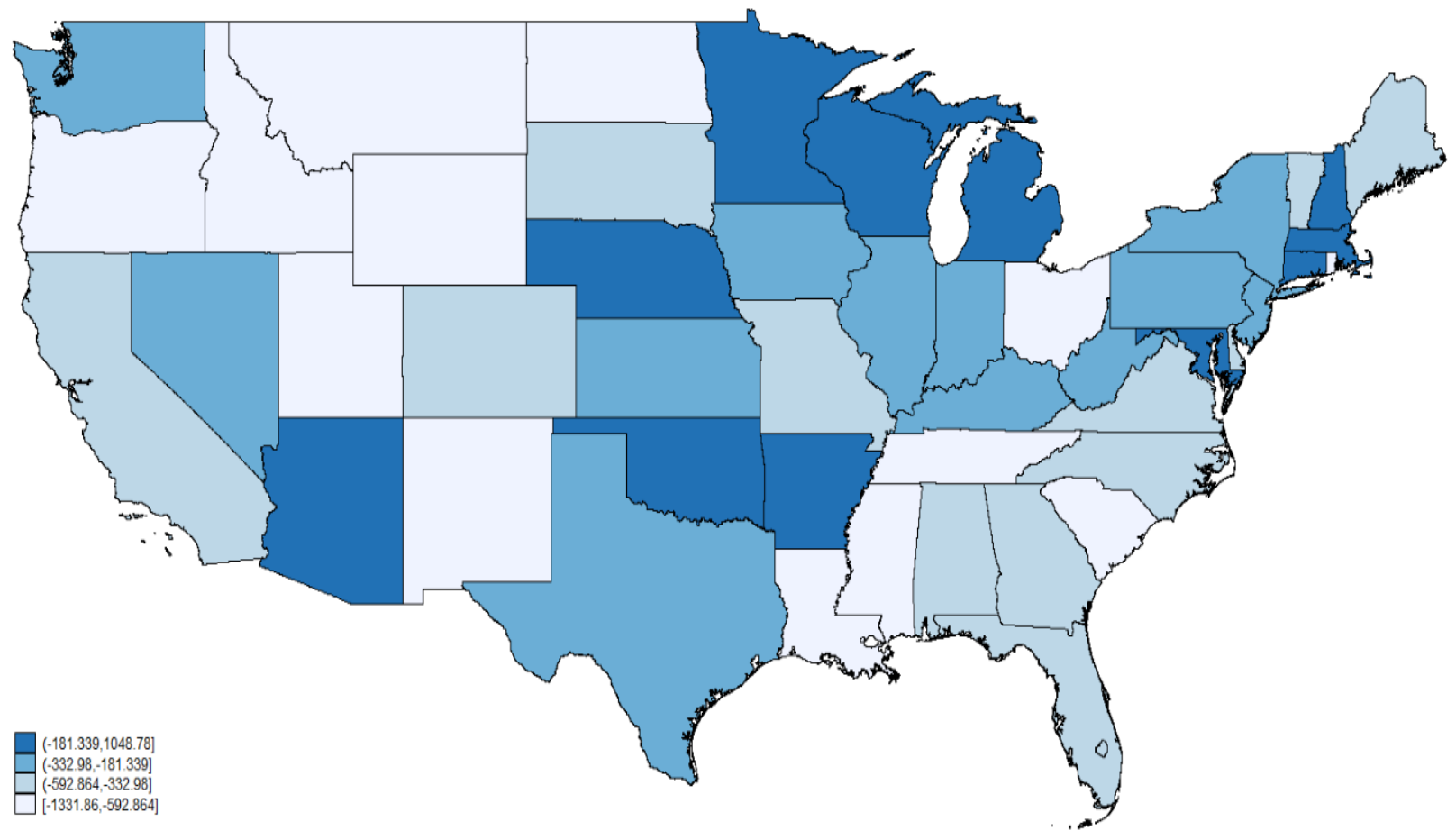

